\title{
Maintaining natural and traditional cultural green infrastructures across Europe: learning from historic and current landscape transformations
}

\author{
Per Angelstam (D) Michael Manton - Taras Yamelynets • Mariia Fedoriak • \\ Andra-Cosmina Albulescu • Felipe Bravo - Fatima Cruz • Bogdan Jaroszewicz (D) \\ Marika Kavtarishvili · Jose Muñoz-Rojas • Frans Sijtsma • Carla-Leanne Washbourne • \\ Mauro Agnoletti · Denis Dobrynin · Zita Izakovicova • Nicklas Jansson • \\ Robert Kanka • Leena Kopperoinen • Marius Lazdinis • Marc Metzger • \\ Bert van der Moolen • Deniz Özut • Dori Pavloska Gjorgieska • \\ Natalie Stryamets $\cdot$ Ahmet Tolunay $\cdot$ Turkay Turkoglu $\cdot$ Asiya Zagidullina
}

Received: 4 July 2020/Accepted: 18 November 2020/Published online: 7 December 2020

(C) The Author(s) 2020

\begin{abstract}
Context Maintaining functional green infrastructures (GIs) require evidence-based knowledge about historic and current states and trends of representative land cover types.

Objectives We address: (1) the long-term loss and transformation of potential natural forest vegetation; (2) the effects of site productivity on permanent forest
\end{abstract}

Electronic supplementary material The online version of this article (https://doi.org/10.1007/s10980-020-01161-y) contains supplementary material, which is available to authorized users.

\section{P. Angelstam $(\bowtie)$}

School for Forest Management, Faculty of Forest Sciences, Swedish University of Agricultural Sciences (SLU), PO Box 43, 73921 Skinnskatteberg, Sweden e-mail: per.angelstam@slu.se

\section{Manton}

Faculty of Forest Science and Ecology, Vytautas Magnus University, Studentu 11, Kaunas District,

53361 Akademija, Lithuania

e-mail: michael.manton@vdu.lt

T. Yamelynets

Faculty of Geography, Ivan Franko National University, Doroshenko Street 41, Lviv 79000, Ukraine

e-mail: taras.yamelynets@gmail.com loss and emergence of traditional cultural landscapes; (3) the current management intensity; and (4) the social-ecological contexts conducive to GI maintenance .

Methods We selected 16 case study regions, each with a local hotspot landscape, ranging from intact forest landscapes, via contiguous and fragmented forest covers, to severe forest loss. Quantitative open access data were used to estimate (i) the historic change and (ii) transformation of land covers, and (iii) compare the forest canopy loss from 2000 to 2018.

\author{
M. Fedoriak \\ Department of Ecology and Biomonitoring, Chernivtsi \\ National University, 2 Kotsyubynski Street, \\ Chernivtsi 58029, Ukraine \\ e-mail: m.m.fedoriak@gmail.com
}

\footnotetext{
A.-C. Albulescu

Department of Geography, Faculty of Geography and Geology, Alexandru Ioan Cuza University of Iaşi, Bd. Carol I no. 11, 700506 Iaşi, Romania e-mail: cosminaalbulescu@yahoo.com

\section{F. Bravo}

Sustainable Forest Management Research Institute iuFOR, University of Valladolid, Campus de la Yutera. Av. de Madrid 44, 34071 Palencia, Spain e-mail: fbravo@pvs.uva.es
} 
Qualitative narratives about each hotspot landscape were analysed for similarities (iv).

Results While the potential natural forest vegetation cover in the 16 case study regions had a mean of $86 \%$, historically it has been reduced to $34 \%$. Higher site productivity coincided with transformation to nonforest land covers. The mean annual forest canopy loss for 2000-2018 ranged from 0.01 to $1.08 \%$. The 16 case studies represented five distinct social-ecological contexts (1) radical transformation of landscapes, (2) abuse of protected area concepts, (3) ancient cultural landscapes (4) multi-functional forests, and (5) intensive even-aged forest management, of which 1 and 4 was most common.

Conclusions GIs encompass both forest naturalness and traditional cultural landscapes. Our review of PanEuropean regions and landscapes revealed similarities in seemingly different contexts, which can support knowledge production and learning about how to sustain GIs.

Keywords Cultural landscape - Forest naturalness · Green infrastructure - Landscape history $\cdot$ Landsharing and land-sparing · Social-ecological system · Reference landscape

F. Cruz

Department of Psychology. Sustainable Forest

Management Research Institute iuFOR, University of

Valladolid, Campus de la Yutera. Av. de Madrid 44,

34071 Palencia, Spain

e-mail: fatimaregina.cruz@uva.es

B. Jaroszewicz

Białowieża Geobotanical Station, Faculty of Biology,

University of Warsaw, ul. Sportowa 19,

17-230 Białowieża, Poland

e-mail: b.jaroszewicz@uw.edu.pl

M. Kavtarishvili

LL.M European and International Law School, Tbilisi, Georgia

e-mail: kavtarishvilim@gmail.com

J. Muñoz-Rojas

MED-Mediterranean Institute for Agriculture, Food and the Environment, Universidade de Évora, Núcleo da Mitra Gab. 206, Edifício dos Regentes Agrícolas. Apartado 94, 7006-554 Évora, Portugal

e-mail: jmrojas@uevora.pt

\section{Introduction}

Across the European continent, biodiversity conservation involves the maintenance of functional habitat networks that represent visions of both forest naturalness (Peterken 1996; EEA 2006) and of traditional cultural landscapes, created and managed during Millennia (Agnoletti and Emanueli 2016). Sauer (1925, p. 46) nicely summarized this: The cultural landscape is fashioned from a natural landscape by a culture group. Culture is the agent, the natural area is the medium, the cultural landscape is the product. Under both conservation visions, securing viable populations of species, and multi-functional landscapes' delivery of multiple ecosystem services, sufficient amounts of areas made up of land cover patches with appropriate ecological quality, size and connectivity are needed. Depending on the conservation vision, maintenance of natural processes or of low-intensity agricultural management is necessary (Halada et al. 2011). Additionally, spatial planning of representative ecological networks encompassing integration of protection, management and landscape restoration (Mansourian et al. 2020) is needed, and which is implemented through collaborative landscape stewardship (Muñoz-Rojas et al. 2015). This argumentation is well reflected in the Convention on Biodiversity' Aichi target 11 (CBD 2010) and the

\author{
F. Sijtsma \\ Faculty of Spatial Sciences, University of Groningen, \\ PO Box 800, 9700 AV Groningen, The Netherlands \\ e-mail: f.j.sijtsma@rug.nl \\ C.-L. Washbourne \\ Department of Science, Technology, Engineering and \\ Public Policy, University College London, Gower Street, \\ London, UK \\ e-mail: c.washbourne@ucl.ac.uk \\ M. Agnoletti \\ Scienze e Tecnologie Agrarie, Alimentari, Ambientali e \\ Forestali (DAGRI), Università di Firenze, Via San \\ Bonaventura, 13, 50145 Florence, Italy \\ e-mail: mauro.agnoletti@unifi.it \\ D. Dobrynin \\ Department of Geographical and Historical Studies, \\ University of Eastern Finland, P.O. Box 111, \\ 80101 Joensuu, Finland \\ e-mail: denis.dobrynin@uef.fi
}


current Zero draft about functional protected area networks (CBD 2020), and also in European policy about green infrastructure (here after GI) (European Commission 2013, 2020).

Despite these clear policy ambitions, the decline of biodiversity continues at unprecedented rates (IPBES 2019; EU 2020). This shows that the implementation and enactment of GI policy for biodiversity conservation and human well-being has not been effective. There are also conflicts between improving the delivery of such non-marketed ecosystem services on the one hand, and intensified wood and biomass production on the other (Verkerk et al. 2014). Thus, the current intensification of industrial forestry with increased harvested area and biomass reduction, especially in the Nordic and Baltic countries and on the Iberian Peninsula (Ceccherini et al. 2020), frequently under the umbrella concept of wood-based bio-economy (Pülzl et al. 2014) challenges the idea of sustainable forest management via increased pressures on GI functionality in both cultural and forest landscapes (Burrascano et al. 2016; Angelstam et al. 2018, 2020a; Svensson et al. 2019). The transformation of near-natural forest remnants to intensively managed boreal forest (e.g., Jonsson et al. 2016, 2019; Svensson et al. 2019), as well as of traditional cultural wooded landscapes to tree plantations, intensive agriculture or urban areas (Burrascano et al. 2016;

\footnotetext{
Z. Izakovicova $\cdot$ R. Kanka

Institute of Landscape Ecology, Slovak Academy of

Sciences, Štefánikova 3, P.O. Box 254, 81499 Bratislava,

Slovakia

e-mail: zita.izakovicova@savba.sk

R. Kanka

e-mail: Robert.Kanka@savba.sk

N. Jansson

IFM Biology, Conservation Ecology Group, Linköping University, Linköping, Sweden

e-mail: nicklas.jansson@liu.se

L. Kopperoinen

Biodiversity Centre, Finnish Environment Institute SYKE, Latokartanonkaari 11, 00790 Helsinki, Finland e-mail: leena.kopperoinen@ymparisto.fi

\section{Lazdinis}

Directorate-General for Agriculture and Rural

Development, European Commission, Brussels, Belgium

e-mail: Marius.LAZDINIS@ec.europa.eu
}

Manton and Angelstam 2018; Bobiec et al. 2019), thus continues. However, traditional multifunctional forest and woodland management approaches through which both timber and non-timber products are delivered simultaneously together with other ecosystem services, including immaterial landscape values, are also important for the development and enhancement of non-wood value chains (Blanco et al. 1997; Jonsson et al. 2019; Angelstam et al. 2020b). For example, reforestations made in Spain in the late 19th and early twentieth centuries to control erosion, became protected areas a century later [i.e., Sierra Espuña, in SE Spain (Vallejo 2005)], and areas where transitions from wood to non-wood products have contributed to stabilize declining rural populations [i.e., Tierra de Pinares in Central-North Spain (Segur 2014)]. This stresses the need to assess the net consequences on biodiversity conservation and ecosystem services of (1) continued transformation of remnants of land covers with high levels of naturalness and/or biocultural authenticity towards land covers managed for maximum sustained yield of fibre, food, feed and fuel, and of (2) establishment of protected areas, voluntary set-asides and other nature consideration, as well as sustaining traditional low-intensity farming systems.

Contemporary research on rural land-use change and GI focuses either on statistical (EUROSTAT 2019) and remote sensing-based data covering the

\footnotetext{
M. Metzger

GeoSciences, The University of Edinburgh, Drummond Street, Edinburgh EH8 9XP, UK

e-mail: marc.metzger@ed.ac.uk

B. van der Moolen

Bosgroep Noord-Oost Nederland, Balkerweg 48a,

7738 PB Witharen, The Netherlands

e-mail: b.vandermoolen@bosgroepen.nl

D. Özut

Nature Conservation Centre, Aşağ 1 Öveçler Mah. 1065. Cad. 1293. Sok. 9/32 Çankaya, Ankara, Turkey

e-mail: denizozut@gmail.com

D. P. Gjorgieska

Head Office/Secretariat of the Regional Rural

Development Standing Working Group (SWG) in SEE, Blvd Goce Delcev 18, 1000 Skopje, North Macedonia e-mail: dori.pavloska@swg-seerural.org
} 
entire European Union such as CORINE land cover (COPERNICIS 2019), or on detailed studies of single high-nature-value landscapes and farming systems affected by imminent threats (e.g., Godinho et al. 2014). To address the challenge of maintaining representative GIs in different social-ecological and cultural contexts, this study applies an intermediate approach based on multiple case studies (e.g., Chmiliar 2010). In addition, consistent with Inglehart (2018), we advocate choosing sampling units that cover the full range of historical, cultural and socialecological situations across the European continent. This approach also strengthens relationships between variables by increasing the range of parameter values (e.g., Roberge et al. 2008; Angelstam et al. 2017a, b; Inglehart 2018). This study thus aims at representing a wide range of contexts from intact forest landscapes in the Pan-European far north (Potapov et al. 2008) with the last primary forests, and high nature value cultural landscapes in Central Europe and the Mediterranean (e.g., Plieninger et al. 2006), both with highly functional GIs, to landscapes that have been severely deteriorated and require landscape restoration. The effects of forest loss and transformation take long time to develop (e.g., Lotz 2015), and different regions are in different phases of this development (Naumov et al. 2016, 2018). This allows for a "replacing time with space" natural experiment approach (e.g., Diamond

\section{N. Stryamets}

Nature Reserve "Roztochya", Sitchovuh Strilciv 7, Ivano-Frankove 81070, Ukraine

e-mail: natastr@gmail.com

\section{A. Tolunay}

Faculty of Forestry, Isparta Unıversity of Applied

Sciences, Isparta 32000, Turkey

e-mail: ahmettolunay@isparta.edu.tr

T. Turkoglu

Department of Forestry, Koycegiz Vocational School, Mugla Sitki Kocman University, 48800 Mugla, Turkey e-mail: turkayturkoglu@mu.edu.tr

A. Zagidullina

Department of Ecology and Vegetation Science, SaintPetersburg State University, Saint-Petersburg, Russia 199034

e-mail: azagidullina@gmail.com
1983; Angelstam et al. 2003a, b, 2011). The PanEuropean diversity of landscape histories, land ownerships, governance/government legacies, cultural meanings and values as well as socio-economic situations (e.g., Inglehart 2018) stresses the need for locally and regionally adapted solutions (Lazdinis et al. 2019; Angelstam et al. 2019). A Pan-European perspective also offers opportunities to support knowledge production and learning about how to sustain GI through comparative studies of regions and landscapes across the European continent as a "time machine" (e.g., Angelstam et al. 2011).

The aim of this study is to identify barriers and opportunities to maintain GI through comparisons of 16 selected case study areas at regional and landscape scales. First, we assess the long-term loss of potential natural forest vegetation in Europe since pre-historic times. Second, we estimate the effects of site class productivity on forest loss and emergence of cultural landscapes. Third, through analyses of recent forest and woodland canopy loss we estimate the current management intensity. Fourth, we use narratives about how GI states are dealt with to identify characteristic contexts for maintaining representative GIs.

\section{Methodology}

Overview of approach

In the context of GI as functional habitat networks, analyses of both pattern and process in landscapes as socio-ecological systems need to be place-based, and reflect sufficient spatial extents and multiple spatial scales. In Fig. 1 we present an overview of our comparative mixed-method approach for assessing GI functionality using a suite of mixed quantitative and qualitative methods.

The aim of this approach is to help identify and characterize different contexts for the maintenance of representative GIs (Fig. 1a). The key strategy is to apply a multiple case study approach that mirrors the range of anthropogenic impacts on GIs on the European continent (e.g., Manton and Angelstam 2018). The lack of opportunity to experiment with long-term trajectories of landscape pattern can be replaced by comparing different areas. The European continent can be considered as a "time machine" for knowledge production and learning (sensu Angelstam 


\section{A mixed-method multiple case study approach for assessing Green Infrastructure functionality}

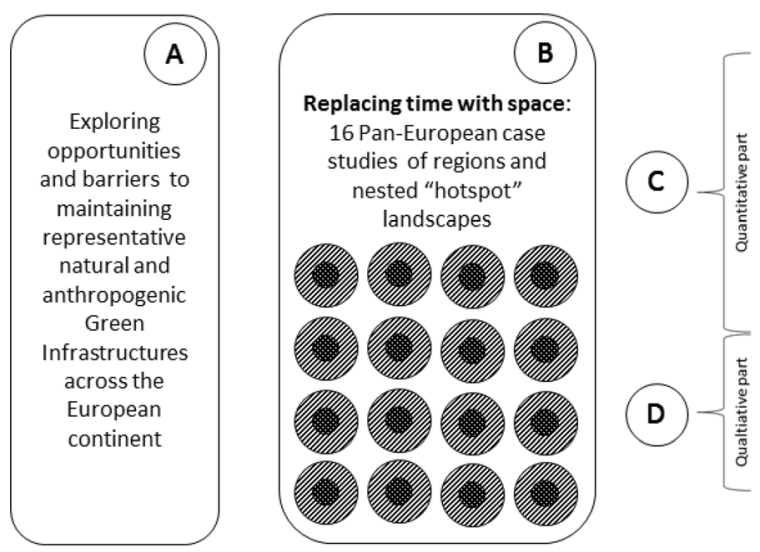

Fig. 1 Overview of the research process from the general aim, through the selection of case study areas at two nested scales, as well as the quantitative and qualitative data sources and four

et al. 2011; FitzHugh and Vogel 2011) about the consequences of human footprints on regions and landscapes with different environmental histories (von Thünen 1826). The reason is that the European continent hosts wide gradients concerning the functionality of habitat networks of both natural and cultural landscape remnants. Due to differences in the development of the human footprint on nature these range from the last large intact forest landscapes (Yaroshenko et al. 2001; Potapov et al. 2008, 2017; Jonsson et al. 2019) and traditional rural cultural landscapes (Plieninger et al. 2006) in the European continent's economic peripheries, to intensively managed landscapes in the core economic regions (Van Eupen et al. 2012). Inclusion of countries and regions both within the European Union and those from the European continent's east also ensures that a range of different present contexts and approaches for GI maintenance (Filepné Kovács et al. 2013), and trajectories of governance cultures (e.g., Inglehart 2018), are represented.

This macroecological approach allows for a selection of cases study areas with widely differing ecological, landscape history and governance contexts that have affected GIs in different ways. For each of these case study areas relevant data for both ecological and social systems were collected using multiple methods. Each case study area reflects two spatial extents: a hotspot landscape and an embedding region

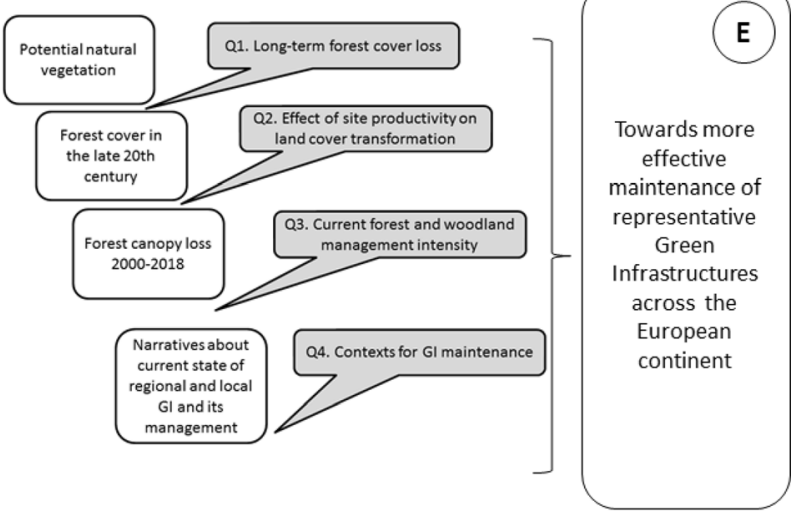

research questions, all aiming at more effective maintenance of representative Green Infrastructures across the European continent

around it. Ecologically, relying on the focal species approach (Lambeck 1997) to define a spatial extent of an ecological system is appropriate. For example, using specialized and area-demanding avian focal species area requirements for a local populations to define a spatial planning unit, the required spatial extent is in the order of $1000-10,000 \mathrm{~km}^{2}$ (Angelstam and Dönz-Breuss 2004, p. 435). These spatial extents correspond to research about entire socio-ecological systems (Singh et al. 2013), and those of local and regional administrative units as focal areas for planning, both in EU and non-EU countries in Europe (e.g., Angelstam et al. 2019). Following the terminology of Stake $(1995,2003,2013)$ each unit of study in this article is a "bounded" separate entity in terms of place and physical boundaries hosting a neighbourhood, organizations, or cultures. With a single case study approach one can do in-depth exploration of a specific bounded system. Based on 16 different cases as a "collective case design" (B in Figs. 1, and 2), with several instrumental bounded cases, we aimed at gaining in-depth understanding of the opportunities and barriers for GI maintenance; much more than any single case can provide (Yin 2002; Chmiliar 2010).

For each of the 16 selected case study regions and constituent hotspot landscapes we addressed the four research questions. First, we performed a tripartite quantitative analysis (Fig. 1c) consisting of (Q1) assessment of the long-term loss of pre-historic 
Table 1 List of case study regions and constituent local hotspot landscapes chosen on the European continent

\begin{tabular}{|c|c|c|c|c|c|}
\hline Country & $\begin{array}{l}\text { ID on } \\
\text { Fig. } 2\end{array}$ & Case study region & Size of region $\left(\mathrm{km}^{2}\right)$ & Local hotspot landscape & $\begin{array}{l}\text { Size of } \\
\text { hotspot } \\
\text { landscape } \\
\left(\mathrm{km}^{2}\right)\end{array}$ \\
\hline \multicolumn{6}{|l|}{$50 \%$ forest cover } \\
\hline Russia (N) & 1 & $\begin{array}{l}\text { Pinega river basin plus buffer } \\
\text { in five Arkhangelsk } \\
\text { districts }^{\dagger}\end{array}$ & 92,232 & Dvina-Pinega forest massif & 9129 \\
\hline Russia (W) & 2 & Pskov oblast & 55,300 & Strugi Krasnye district & 3090 \\
\hline Sweden (S) & 3 & $\begin{array}{l}\text { Örebro county and Karlsborg } \\
\text { municipality }\end{array}$ & $8,546+797$ & $\begin{array}{l}\text { Laxå municipality with } \\
\text { Tiveden national park }\end{array}$ & 743 \\
\hline Sweden $(\mathrm{N})$ & 4 & Jokkmokk municipality & 19,344 & Kvikkjokk & 419 \\
\hline \multicolumn{6}{|l|}{$20-50 \%$ forest cover } \\
\hline Austria & 5 & Vorarlberg & 2601 & Montafon's 10 villages $^{\dagger \dagger}$ & 560 \\
\hline Georgia & 6 & Kakheti region & 11,311 & $\begin{array}{l}\text { Tusheti province in Akhmeta } \\
\text { municipality }\end{array}$ & 969 \\
\hline Lithuania & 7 & Dzukija ethnographic region & 13,149 & Dzukija NP and Cepkeliu NR & 697 \\
\hline $\begin{array}{l}\text { North Macedonia } \\
\text { Albania, Kosovo }\end{array}$ & 8 & $\begin{array}{l}\text { The municipalities Jegunovce } \\
\text { and Tearce in North } \\
\text { Macedonia, Prizren, } \\
\text { Shterpce/Strpce and } \\
\text { Dragash in Kosovo, and the } \\
\text { district of Kukes in Albania }\end{array}$ & $\begin{array}{l}2564 \text { (311 in North } \\
\text { Macedonia, } 930 \text { in Albania } \\
\text { and } 1323 \text { in Kosovo) }\end{array}$ & $\begin{array}{l}\text { Sharr Mountains National } \\
\text { Park }\end{array}$ & 533 \\
\hline Poland, Belarus & 9 & $\begin{array}{l}\text { Podlaskie wojewodstvo } \\
\text { covering most of the Narew } \\
\text { basin, and three Belarusian } \\
\text { districts }^{\dagger \dagger \dagger}\end{array}$ & 39,800 & $\begin{array}{l}\text { Bialowieza forest WHS in PL } \\
\text { and BY (UNESCO 2018) }\end{array}$ & 2391 \\
\hline Scotland & 10 & Lochaber & 4654 & Loch Sunart & 322 \\
\hline Slovakia & 11 & Trnava and Bratislava regions & $4145+2053$ & Trnava district & 741 \\
\hline Ukraine, Romania & 12 & $\begin{array}{l}\text { Chernivtsi oblast and } \\
\text { Suceava county }\end{array}$ & $8097+8553$ & Putyla district & 884 \\
\hline \multicolumn{6}{|l|}{$<20 \%$ forest cover } \\
\hline Netherlands & 13 & Fryslan (Friesland) & 5749 & Beetsterzwaag project area & 74 \\
\hline Portugal & 14 & Évora district & 7393 & $\begin{array}{l}\text { Sítio de Monfurado, } \\
\text { Montemor-o-Novo }\end{array}$ & 240 \\
\hline Spain & 15 & Palencia province & 8052 & $\begin{array}{l}\text { Palencia Model Forest NE } \\
\text { corner's } 10 \text { municipalities, } \\
\text { and GeoPark in Burgos }{ }^{\dagger \dagger \dagger}\end{array}$ & 637 \\
\hline Turkey & 16 & $\begin{array}{l}\text { Mersin and Karaman } \\
\text { provinces }\end{array}$ & $15,853+9,163$ & $\begin{array}{l}\text { Kösecobanli oak landscape } \\
\text { (in Gülnar municipality) }\end{array}$ & 1413 \\
\hline
\end{tabular}

${ }^{\dagger}$ Kholmogorskyi, Pinezhskiy, Vinogradovskiy, Verkhnetoemskiy, Krasnoborskiy districts

${ }^{\dagger}$ Gaschurn, Sankt Gallenkirch, Schruns, Tschagguns, Silbertal, Bartholomäberg, Vandans, St. Anton im Montafon, Lorüns, Stallehr ${ }^{\dagger \dagger}$ Kamyanets, Prozhany, Svislach districts

${ }^{\dagger+\dagger}$ Municipalities in both GeoPark and Model Forest: Aguilar de Campo, Pomar de Valdivia, Santibanez de Ecla, Alar de Rey; only in Model Forest: Cervera de Pisuerga (southernmost part), Dehesa de Montejo, Mudá, Barruelo de Santullan, Salinas de Pisuerga; and only the GeoPark in Burgos Rebolledo de la Torre 


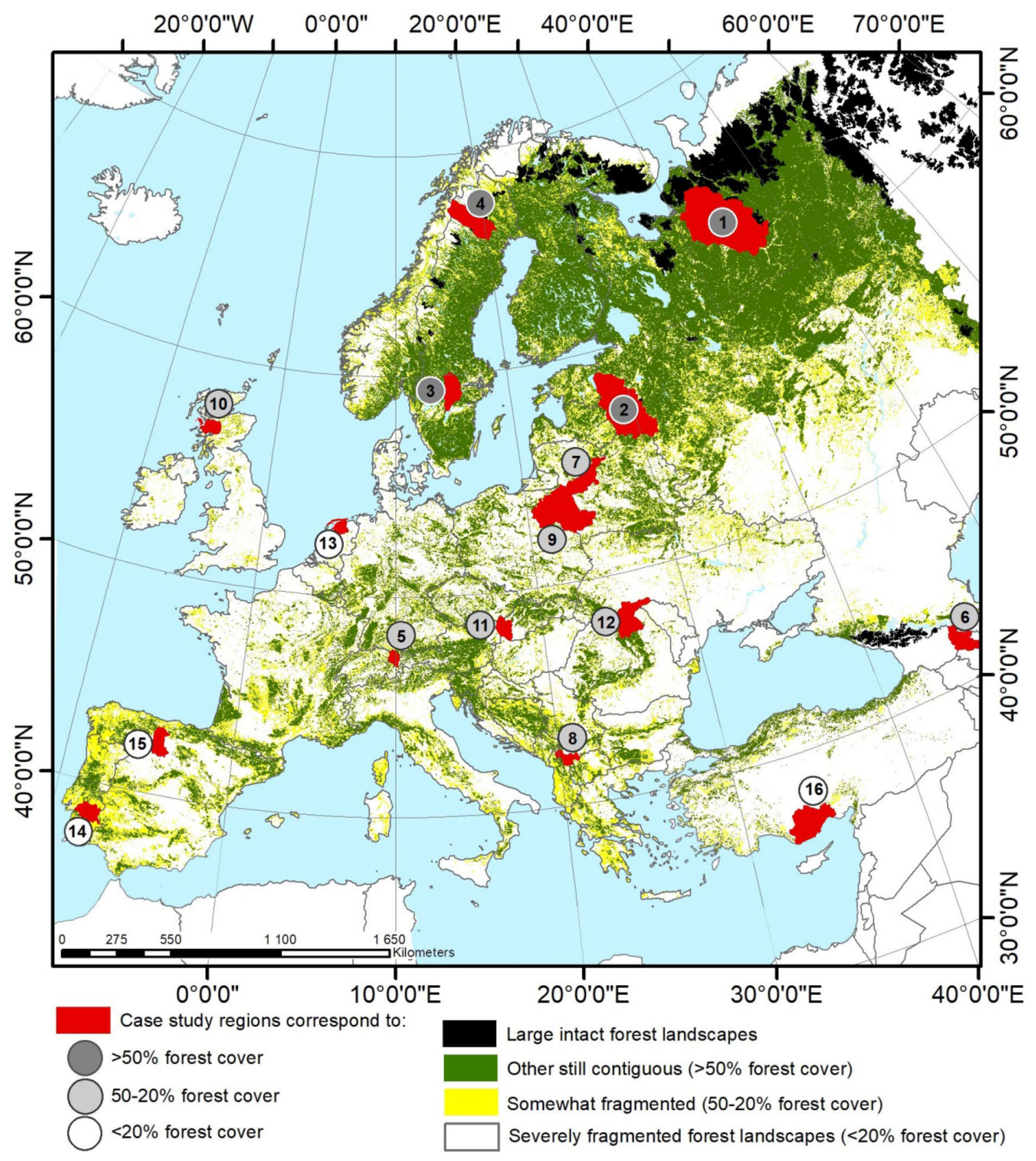

Fig. 2 Map showing the location of 16 case study regions representing the gradient in historic forest fragmentation from intact forest landscapes (Potapov et al. 2008) via other still contiguous ( $>50 \%$ forest cover), somewhat fragmented

potential natural forests vegetation in Europe; (Q2) estimation of the effects of site class productivity on forest loss, and on the emergence of cultural

(50-20\% forest cover) to severely fragmented forest landscapes ( $<20 \%$ forest cover). See Table 1 for description of each case study region and constituent hotspot landscape in the different countries

landscapes; (Q3) analyses of recent forest and woodland canopy loss as a proxy for the current management intensity. Finally, for all cases studies we 
performed qualitative research (Fig. 1d) in which (Q4) we used narratives about how GI states are dealt with to identify characteristic contexts for maintaining representative GIs (Fig. 1e).

Case study regions and hotspot landscapes on the European continent

To embrace the Pan-European diversity of both potential natural forest vegetation types (i.e. a naturalness vision for conservation), and cultural woodland landscapes [i.e. a biocultural vision for conservation (Dobrovodská et al. 2019)], we selected 16 case study regions, each with a nested local hotspot landscape (Fig. 2). Given that the potential natural vegetation in Europe is dominated by forests of different kinds (Bohn et al. 2000, 2003) we choose case study regions with different levels of historical permanent loss forest cover (Figs. 2, 3, Table 1). The regions and hotspot landscapes were chosen (1) to cover different steps in the anthropogenic transformation of potential natural forest vegetation (Kaplan et al. 2009; Zanon et al. 2018; Figs. 3, 4), (2) to span the long gradient of different environmental histories, (3) that suitable co-authors with in-depth knowledge about each hotspot landscape could be recruited, and (4) to mirror cultural differences sensu Inglehart
(2018) for a parallel study focusing on landscape stewardship (Angelstam et al. in press). To maintain clarity regarding each couple of case study region and hotspot landscape, which have different names, we refer to the relevant country throughout (see Table 1).

Habitat loss has consequences for species' abilities to move within and across landscapes. The rationale for the case study selection was to capture the gradient in forest naturalness (e.g., Peterken 1996) in three coarse steps linked to historic habitat loss on the European continent over Millennia. Thus, in the European Union area, only $3 \%$ of land areas are strictly protected, but with some large intact forest landscapes still left in the north (Jonsson et al. 2019), and $<1 \%$ remains of near-natural remnants in the south (Hannah et al. 1995, European Commission 2020). To improve the situation the European Commission (2020) put forward the target that at least one third of protected areas (representing 10\% of the land area) should be strictly protected; this does not necessarily mean not being accessible to humans, but should leave natural processes essentially undisturbed. The focus on strict protection stresses the need to define, map, monitor and strictly protect all the EU's remaining primary and old-growth forests on the one hand, and on the cultural landscapes that emerged on the other. We thus selected case study regions that

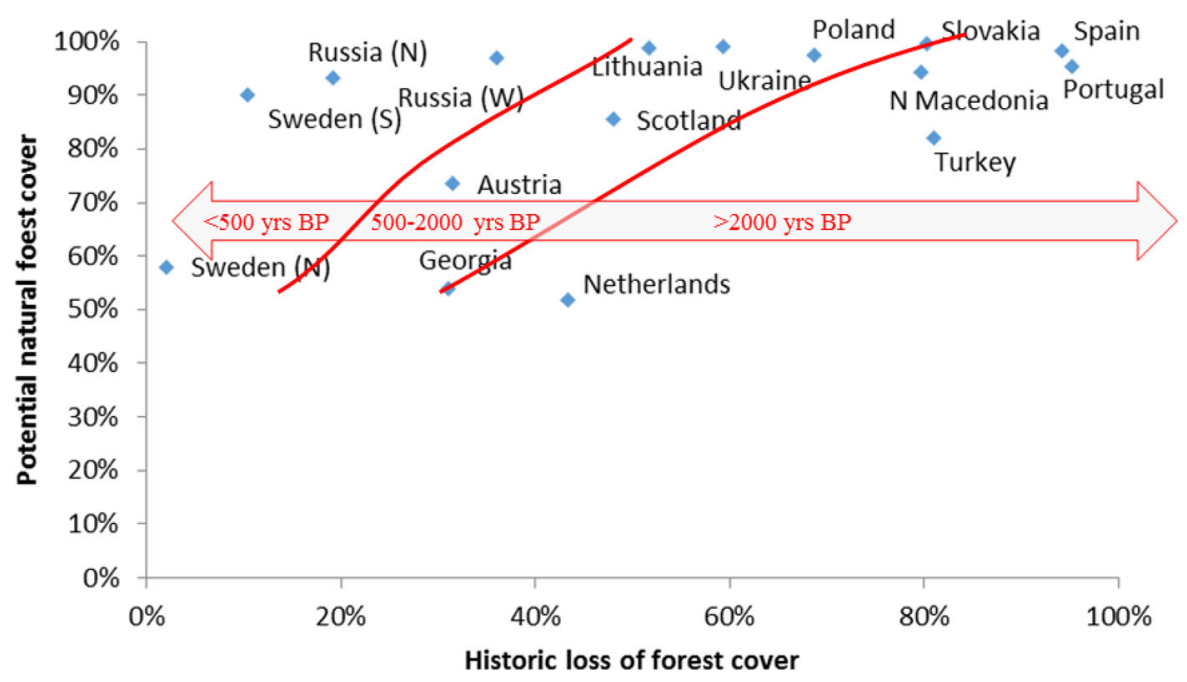

Fig. 3 Comparison of potential natural forest cover in 16 case study regions (Table 1) on the European continent (Bohn et al. 2000,2003 ), and the historic loss of potential natural forest cover due to transformation of forests to traditional cultural landscapes, agriculture and urban areas (Broxton et al. 2014). The mean and median potential natural forest covers were $86 \%$ and $93 \%$, respectively. The time line with three periods and the associated isolines (in red in the on-line pdf) indicate the approximate duration of the process of historic loss of potential natural forest cover, and creation of traditional cultural landscapes (see Kaplan et al. 2009; Zanon et al. 2018 for details) 


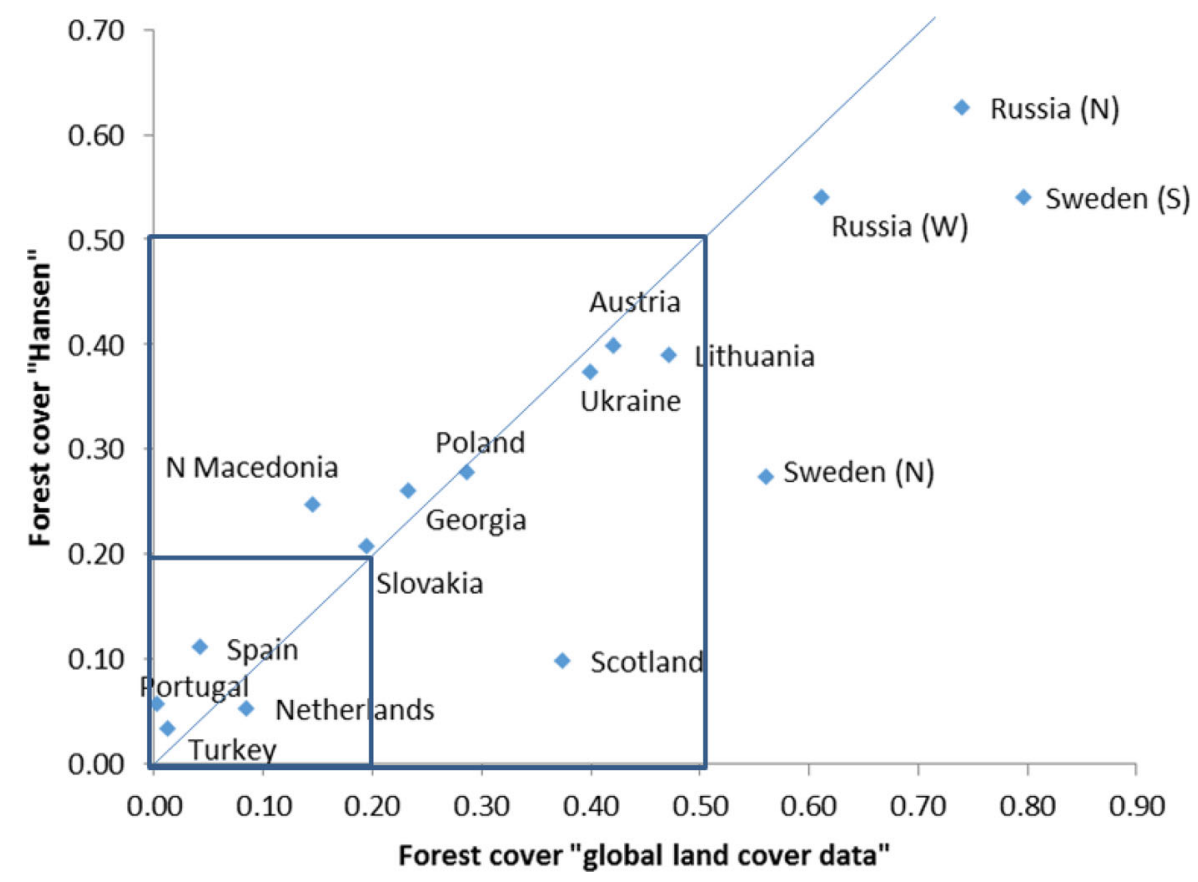

Fig. 4 Comparison between the current forest land cover in the 16 case study regions according to Hansen et al. (2013) and Broxton et al. (2014), respectively. The line through origo is the 1:1 ratio. A 50\% habitat loss illustrating a percolation threshold

represent three groups; viz., (1) unfragmented forest covers, i.e. not exceeding percolation thresholds (c.f. With and Crist 1995) of $<50 \%$ historic forest loss representing a contiguous forest cover, (2) fragmented forests with 50 to $80 \%$ of historic forest loss, and (3) historic forest loss below the fragmentation threshold representing a historic forest loss of $>80 \%$ (Bascompte and Solé 1996; Fahrig 2018). The third group is, however, often linked to transitions from forests to traditional cultural landscapes encompassing both cultural heritage and biocultural values (Agnoletti 2014). The mean and median sizes of the regions selected were 19,955 and $5332 \mathrm{~km}^{2}$, respectively (Table 1), and the mean and median sizes of the hotspots were 1428 and $719 \mathrm{~km}^{2}$, respectively (Table 1).

Methods

\section{Potential natural forest vegetation and current land} covers

There are many different representative naturally dynamic types of forest vegetation and anthropogenic is denoted by the big square, and fragmentation thresholds representing $70-90 \%$ habitat loss (here mean of $80 \%$ ) habitat loss is illustrated by the small square

land cover types in any given region, all involving a diversity of species, habitats and processes across different spatio-temporal scales. Determining the effectiveness of different governance and economic systems for achieving sustainable landscapes relies on a thorough understanding of the resulting composition, structure and function of the land cover types of a region as representative types of GI. This includes (1) base-line knowledge about reference conditions (e.g., Axelsson and Östlund 2001; Östlund et al. 1997; Agnoletti 2014) including how to emulate natural as well as anthropogenic disturbance regimes (e.g., Fries et al. 1997; Plieninger et al. 2006), (2) how the environmental history has modified landscapes historically (Worster 2005; Ranius and Kindvall 2006; Naumov et al. 2016; Manton and Angelstam 2018), and (3) how much current semi-natural forests and tree plantations sensu EEA (2006) or cultural landscapes can differ from reference conditions without passing critical tipping points (e.g., Angelstam et al. 2003a, b, Rompré et al. 2010). The term gap analysis captures this systematic assessment approach (e.g., Scott et al. 1993; Angelstam and Andersson 2001; Angelstam et al. 2017a, b, c). 
The first and second aims of this study were to analyse (1) the permanent loss of forest as the main potential natural vegetation type due to historic land use change, and (2) the transition from natural potential forest vegetation types to current land covers such as managed forests, cultural landscapes, agriculture and grey infrastructure, respectively. With a biodiversity perspective a natural forest ecosystem includes a wide range of different types of dead wood, development stages following natural disturbances, and spatio-temporal dynamic at multiple scales. Consequently, historical "permanent loss of forest vegetation" is therefore estimated conservatively. This is because in generalised land cover data current production forestry with altered tree species transformation and tree plantations aimed at sustained yield biomass production and high standing volume can still be viewed as forest. In contrast, the delivery time for many naturalness properties is much longer (see also below).

We thus analysed the potential natural vegetation land cover for the European continent using the maps at the scale of 1:2,500,000 produced by Bohn et al. (2000, 2003). The map includes a descriptive legend and a detailed explanatory text with a phytogeographical overview of the European continent as well as short descriptions of all mapped units. To estimate current land cover types we used the Land Cover Data developed by Broxton et al. (2014). The raster land cover data (15 arc s) includes 17 land cover classes (evergreen coniferous forest, evergreen broadleaf forest, deciduous coniferous forest, deciduous broadleaf forest, mixed forest, closed shrublands, open shrublands, woody savannahs, savannahs, permanent wetlands, succession areas, grasslands, water bodies, cropland, cropland/natural vegetation, urban areas, snow and ice, bare rocks). For Turkey we used the land cover maps of Atalay et al. (2014) and Raja et al. (2018).

Transformations of potential natural forest cover with their different disturbance regimes to current land covers were clustered into 9 land cover types corresponding to remaining coniferous, mixed and deciduous forests (variable "Forest"), woodlands ("Seminatural"), areas subject to historic forest cover loss (variable "Cropland/Urban"), and other non-forest land covers (variable "Barren"). To rank different types of potential natural vegetation according to their level of primary production we used the principles based on nutrient vs. soil moisture schemes developed by Cajander (1926), Sukachev and Dylis (1964, pp. 82-83), Arnborg (1990) and Hägglund and Lundmark (1977) for boreal forest biomes, by Ellenberg (1988), Leuschner and Ellenberg (2018) and Pogrebnyak (1955, pp. 174-191) for temperate and mountain forests, and by Mayer and Aksoy (1986) and Bravo and Montero (2001) for Mediterranean biomes.

\section{Current forest management intensity}

In both forests and woodlands later successional stages following disturbances generally provide the most valuable habitats for biodiversity conservation (e.g., Dorresteijn et al. 2013). To fulfil the third aim of this study, estimating the contemporary annual forest canopy loss as an indication of forest management intensity, we used the forest loss, i.e. the temporary or permanent forest tree canopy loss, data provided by the Global Forest Change 2000-2018 data set (Hansen et al. 2010, 2013; http://earthenginepartners.appspot. com/science-2013-global-forest). Here forest canopy loss is defined as a stand replacement disturbance, or a change in forest tree canopy to an area of non-forest state. Using GIS (ArcMap 10) we calculated and presented for each $5 \times 5 \mathrm{~km}$ grid cell in the case study regions and hotspot landscapes the following attributes: (i) forest cover in year 2000, (ii) the forest tree canopy loss during the following 18 years, and (iii) the mean annual forest tree canopy loss as proxy for forest management intensity. For example o, a 100-year (e.g., Republic f Lithuania 2001) vs. a 50-year [in UK/ Scotland (e.g., Forestry Commission 2016)] forest rotation corresponds to average annual forest canopy losses of $1 \%$ and $2 \%$, respectively. Over entire forest rotations, from a sustained yield point-of-view, forest canopy loss is temporary because forest canopy gain will maintain the same stand-age distribution, but the chances of becoming old growth are zero in the context of sustained yield forestry. Thus, forest canopy loss does not mean the complete loss of forested area (see Chazdon et al. 2016). Nevertheless, the development of habitat characteristics typical for naturally dynamic forest including old growth forest is generally acknowledged to be 2-3 times longer than the length of common silvicultural cycles (e.g., Esseen et al. 1997). This means that with short rotation focusing on sustained yield the level of naturalness (e.g., Winter 2012) will remain low. Analogously, 
given sufficient time, forest tree canopy cover gain through afforestation and natural succession in abandoned agricultural areas and on non-forest land, could lead to forest landscape restoration in the simplistic meaning of increased tree canopy cover without considering its composition, structure and function.

The mean forest canopy loss 2000-2018 was calculated for each of the 16 regional case study landscapes and hotspots, respectively. Differences in annual forest canopy loss rate between each regional and their respective hotspot landscape indicate higher or lower than average forest management intensities. Nevertheless, forest canopy loss rates mirror trends and differences in forest management intensity (Angelstam et al. 2017a, 2020b; Jonsson et al. 2019).

\section{Narratives about the case studies}

The fourth aim was to identify barriers and opportunities to maintain different types of GI. In contrast to the linear quantitative and deductive research process concerning land cover types and their transformation covered by the three first aims of this study, we applied a qualitative and inductive approach based on mixed methods (Creswell 2007; Greene 2007). We thus used qualitative data through narrative research, which gives priority to the data and the field of GI maintenance in the case study regions and constituent hotspots (c.f., Flick 2006, p. 98, ff.). In this study, for two reasons the co-authors were experts on one or several of the selected 16 case study regions, and constituent hotspot landscapes as social-ecological systems. First each co-author reporting on a case study region and its hotspot had 5-30 years of research experience, and second, they work or live in the area. Based on this, and a literature survey, each case study author built a narrative summarising knowledge about the land use history of the region and the selected constituent hotspot landscape. The narratives were used to understand the social-ecological contexts of the case studies, extract key natural forest and cultural landscape values, as well as indications of bridges and barriers in social-ecological systems to maintain these values.

\section{Results}

Historic loss and transformation of potential natural forest cover

The mean and median potential natural forest covers of the 16 case study regions were $86 \%$ and $93 \%$, respectively (Fig. 3). There was a significant positive correlation between historic forest loss and the potential natural forest cover (Pearson's $r=0.50$, df $=14$, $\mathrm{p}<0.05$, one-tailed test). However, disregarding the case study regions in Sweden (N) with mountain vegetation as a major potential natural vegetation type, Georgia with shrub, steppe and desert vegetation, and the Netherlands with an abundance of coastal open habitats, all three with potential natural forest cover $<$ 0.6 (Fig. 3), the correlation was reduced to $r=0.33$ and insignificant ( $\mathrm{df}=11$, NS, one-tailed test).

Overall, there was a significant correlation between the current regional forest cover estimates according to Broxton et al. (2014) and Hansen et al. (2010, 2013), respectively ( $\mathrm{r}=0.89$, $\mathrm{df}=14, \mathrm{p}<0.001$; Fig. 4). While most regional case study areas fit the 1:1 ratio line for the two forest cover data sets, Scotland and both of Sweden's case study regions ( $\mathrm{N}$ and $\mathrm{S}$ ) had higher forest cover according to Broxton's et al. (2014) than according to Hansen's et al. (2013) data. Thus, with a mean current forest cover of $34 \%$ (median 26\%), the average historic loss of forest cover was 52 and 67 percent units, respectively. Case study regions with unfragmented forest cover $(<50 \%$ forest loss) were represented by the two Russian and Swedish case study regions. The second intermediate group of historic forest loss contains the mountainlowland gradients in the case study regions in Austria, Ukraine, Georgia, N Macedonia, Slovakia and Scotland in the UK, as well as Lithuania and Poland both with steep gradients in productivity from poor sandy soils and rich wet soils. The third group with $>80 \%$ historic forest loss consists of the Netherlands, Spain, Portugal and Turkey. Overall, the higher the site productivity index of potential natural vegetation types, the more the potential natural forest cover had been reduced (Fig. 5), and transformed to semi-natural and crop-urban land covers (Fig. 6). Thus case studies with low historic permanent forest loss $(<50 \%)$ were dominated by pine forests, intermediate forest loss (50-80\%) were dominated by mixed coniferous and deciduous forests, and high forest loss $(>80 \%)$ were 


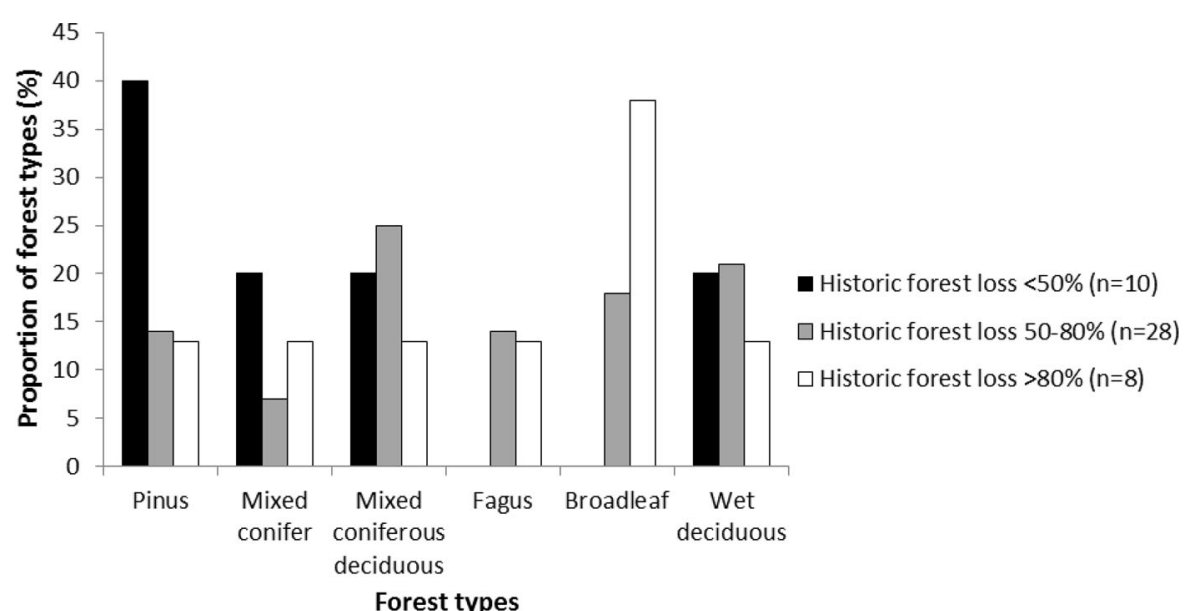

Fig. 5 Distribution of coarse potential natural forest types ranging from low to high site productivity (e.g., Hägglund and Lundmark 1977; Bravo and Montero 2001), among regional case study regions with low, intermediate and high historic forest loss and transformation to other land covers. The sample sizes represent the total number of forest types across the forest regions within the three groups of historic forest loss

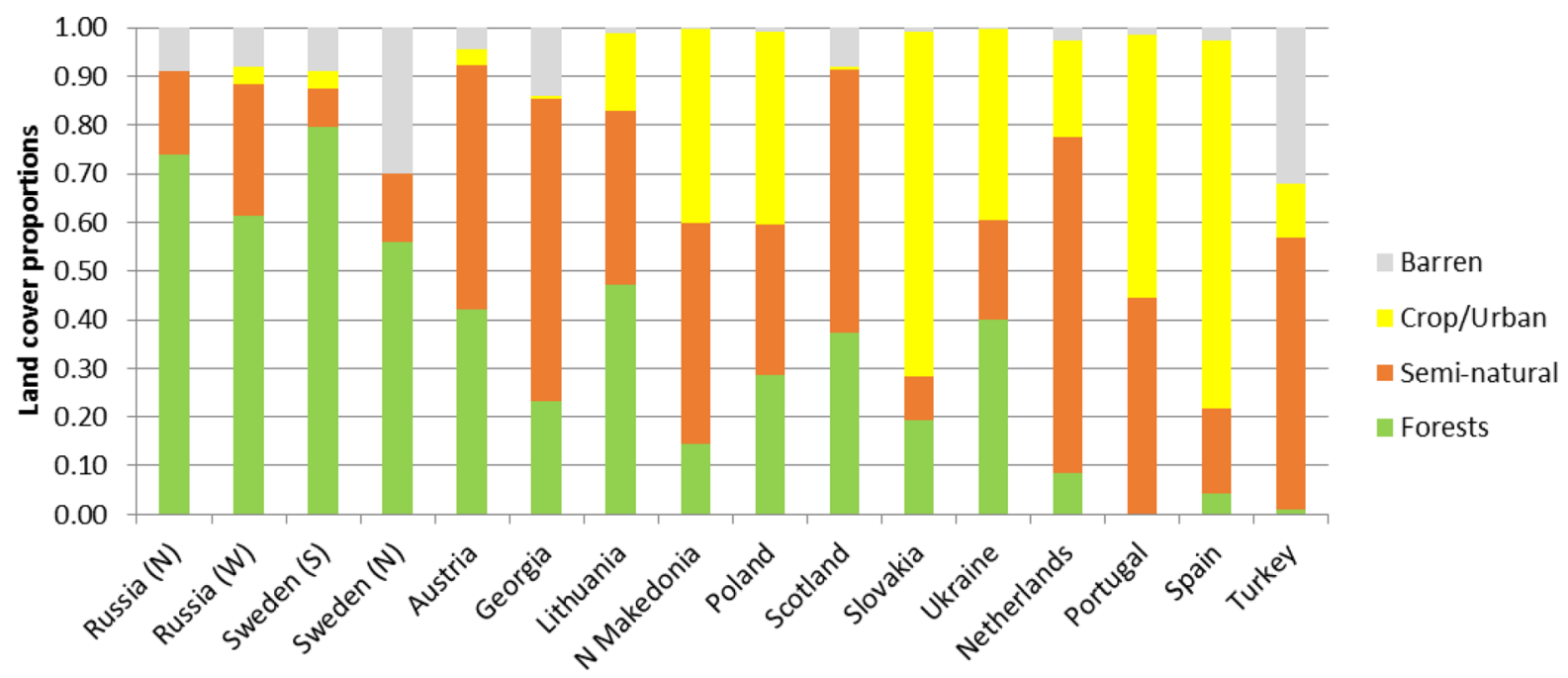

Fig. 6 Current distribution of coarse land cover classes based on Broxton et al. (2014) in the 16 Pan-European case study regions ranked from left to right from lowest to highest historic

dominated by broadleaf forest, Depending on region, this process has been gradual for less than 500 years (e.g., northernmost Europe) to more the two Millennia (e.g., the Mediterranean) (Kaplan et al. 2009, Zanon et al. 2018; see Fig. 3). This coincides with regional patterns of extirpation of specialised or area-demanding species (Mikusiński and Angelstam 2004).

The 16 case study regions thus represented a wide gradient ranging from forest landscapes with a lower level $[\operatorname{Sweden}(\mathrm{S}+\mathrm{N})$ and Russia $(\mathrm{N}+\mathrm{W})]$ to a very loss of potential natural vegetation. In Table 1 the 16 case study regions are grouped into forest loss rates of $<50 \%, 50-80 \%$ and $>80 \%$, respectively

high level (Portugal, Spain, Turkey) of transformation of the original forest into semi-natural and crop/urban land covers (Fig. 6). This gradient ranges from large intact forest landscapes in NW Russia to traditional cultural landscapes on the Iberian Peninsula. Principal Component Analysis (PCA) ordination (Fig. 7) based on land cover data developed by Broxton et al. (2014) showed that the first two components explained $94 \%$ of the variance $(\mathrm{PC} 1=60 \%$ and $\mathrm{PC} 2=34 \%)$. Component 1 represents forest as the most positive factor 


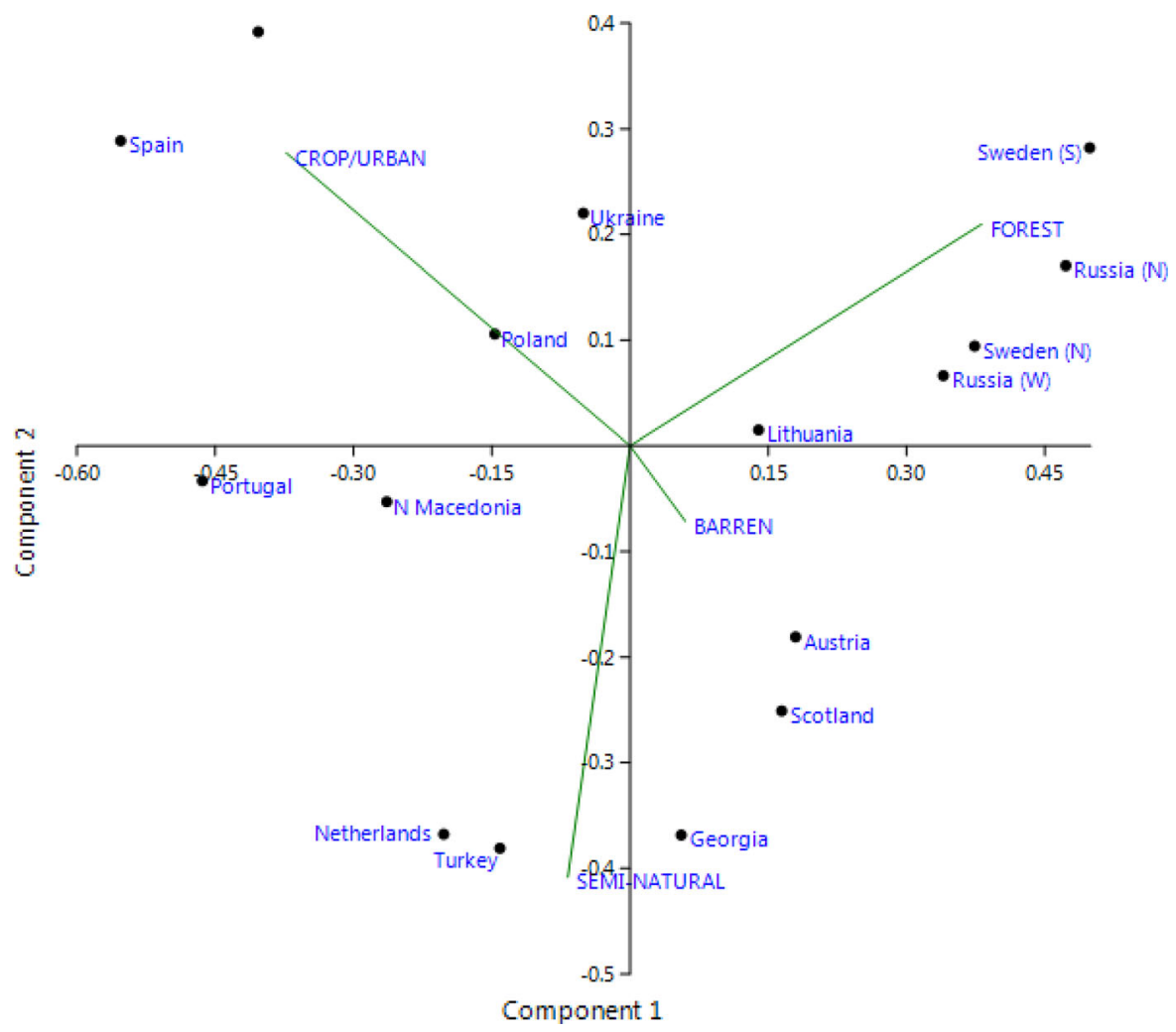

Fig. 7 Ordination of 16 Pan-European case study regions based on the current coarse land covers (Broxton et al. 2014). PCA 1 represent forest as a positive factor and crop/urban as a negative

and crop/urban as the most negative factor, and component 2 represents crop/urban as the most positive factor and semi-natural as the most negative factor. This corresponds to (1) a "forest" cluster of case study regions in Sweden ( $\mathrm{S}$ and N), Russia (N and W) and Lithuania, (2) a semi-natural land cover cluster with Turkey, Netherlands, Scotland, Austria and Georgia, and (3) a crop/urban group with Ukraine, Poland, N Macedonia, Portugal, Slovakia, and Spain (Fig. 8).

\section{Current forest canopy loss}

Focusing on the Hansen et al. (2013) data, the mean forest cover for all 16 case study regions in 2000-2018 was $26 \%$ (range $3-63 \%$ ), the mean annual forest canopy loss was $0.47 \%$ (range $0.01-1.08 \%$ ), and there was no significant correlation between them $(r=-0.08, \mathrm{df}=14$, NS; see Fig. 9). The regional case studies in Portugal, Spain, Turkey and Scotland factor, and PCA 2 represents crop/urban and semi-natural as explanatory variables

stood out with the combination of having both low forest cover and a high level of forest canopy loss.

\section{Landscape narratives reveal Pan-European GI contexts}

To illustrate that the 16 case study regions and the selected constituent hotspot landscapes represent a wide range of contexts of importance for GI maintenance, we plotted the annual forest canopy loss rates at the scale of the regional case studies and the hotspot landscapes (Fig. 10). This shows on the one hand an overall positive correlation $(\mathrm{r}=0.62, \mathrm{p}=0.01)$, as well as interesting deviations from this relationship on the other. Based on the similarities between the forest canopy loss at the regional level vs. in the hotspot landscape we identified five groups representing different contexts for GI maintenance (see Fig. 10).

The first group was case studies with higher forest canopy losses in hotspots compared to their respective case study regions. This pattern was linked to three 


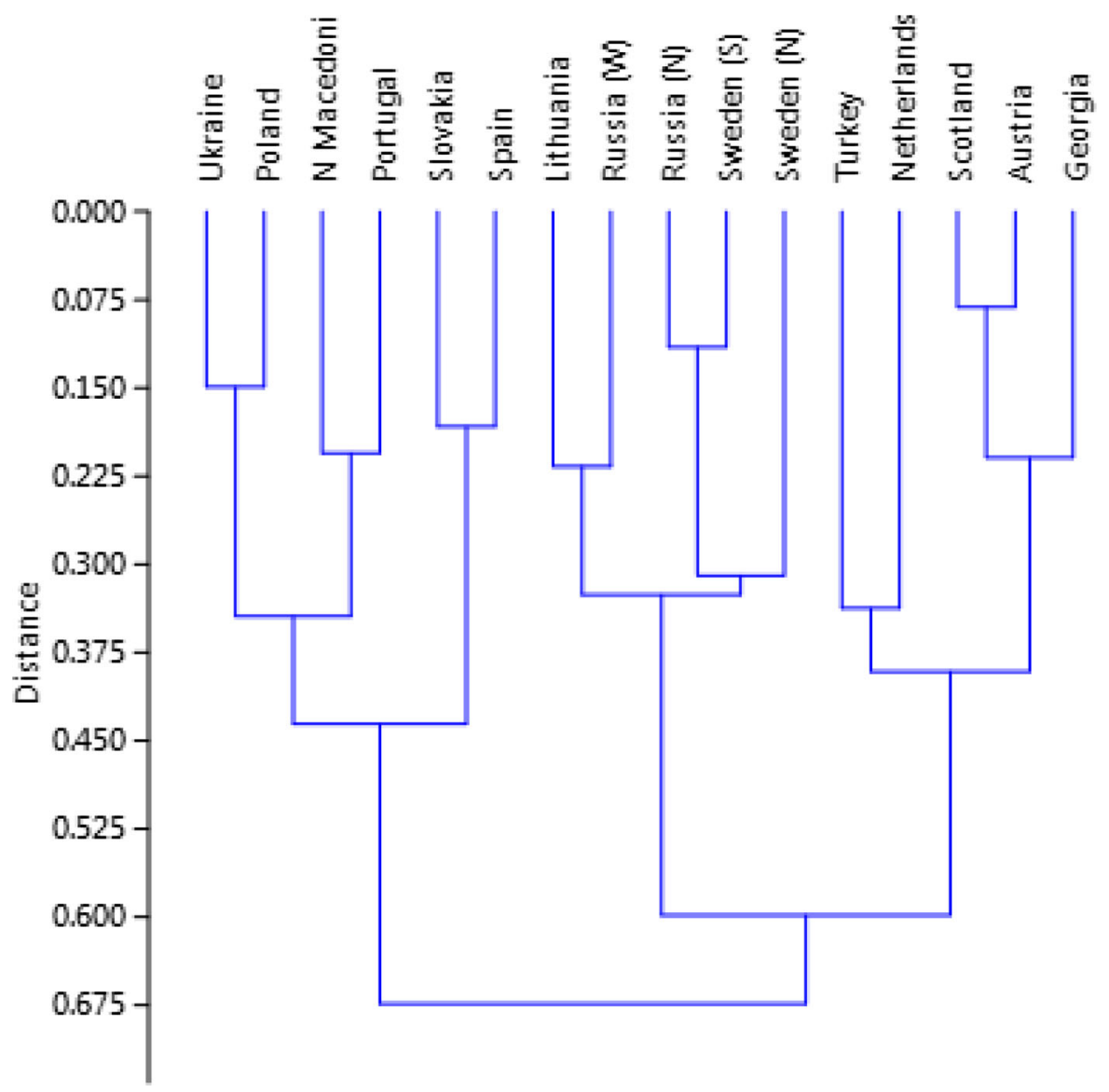

Fig. 8 Ordination of 16 Pan-European case study regions based on the current coarse land covers according to Broxton et al. (2014)

different processes of radical transformation of landscapes. First, the Turkish cultural oak woodlands landscape (e.g., Quercus ithaburensis) of key importance for conservation of species dependent on old trees and a European biodiversity hotspot (e.g., Bergner et al. 2016) is currently being logged and transformed to production-oriented conifer plantations focusing on Cedrus lebani. Second, in the Scottish hotspot landscape there is an inverse transformation process in which production-oriented conifer plantations (Picea sitchensis) (Mather 2004) are being removed, and regeneration of oak woodlands is enhanced by planting and fencing (see Online Appendix). In the rest of Scotland commercial plantations remain dominant (although better managed and more diverse in new plantings). Combined objective forestry better recognise the reality on the ground. Third, the north Russian case study region contains one of the last remaining intact forest landscapes
(Potapov et al. 2008) in Europe. Located at the edge one of the last frontiers of wood mining in European primary forests, this hotspot landscape covering $>9000 \mathrm{~km}^{2}$ is subject to final felling of primeval forest remnants (e.g., Karpov 2019; Blumröder et al. 2020). About a third of this intact forest landscape was transformed into a protected area in 2019 (see Online Appendix). Similar processes of forest canopy loss are taking place in this case study group where forests that were historically subject to low rates of natural disturbance, continuous cover forestry systems, or low intensity tree and group selection systems, are being replaced by clear-felling followed by natural regeneration, such as in western Russia (Knize and Romanyuk 2006) and the Ukrainian Carpathian Mountains (Kuemmerle et al. 2009; Keeton et al. 2013; Spracklen and Spracklen 2020).

The second group is formed by the Polish and Lithuanian case study regions and hotspot landscapes. 


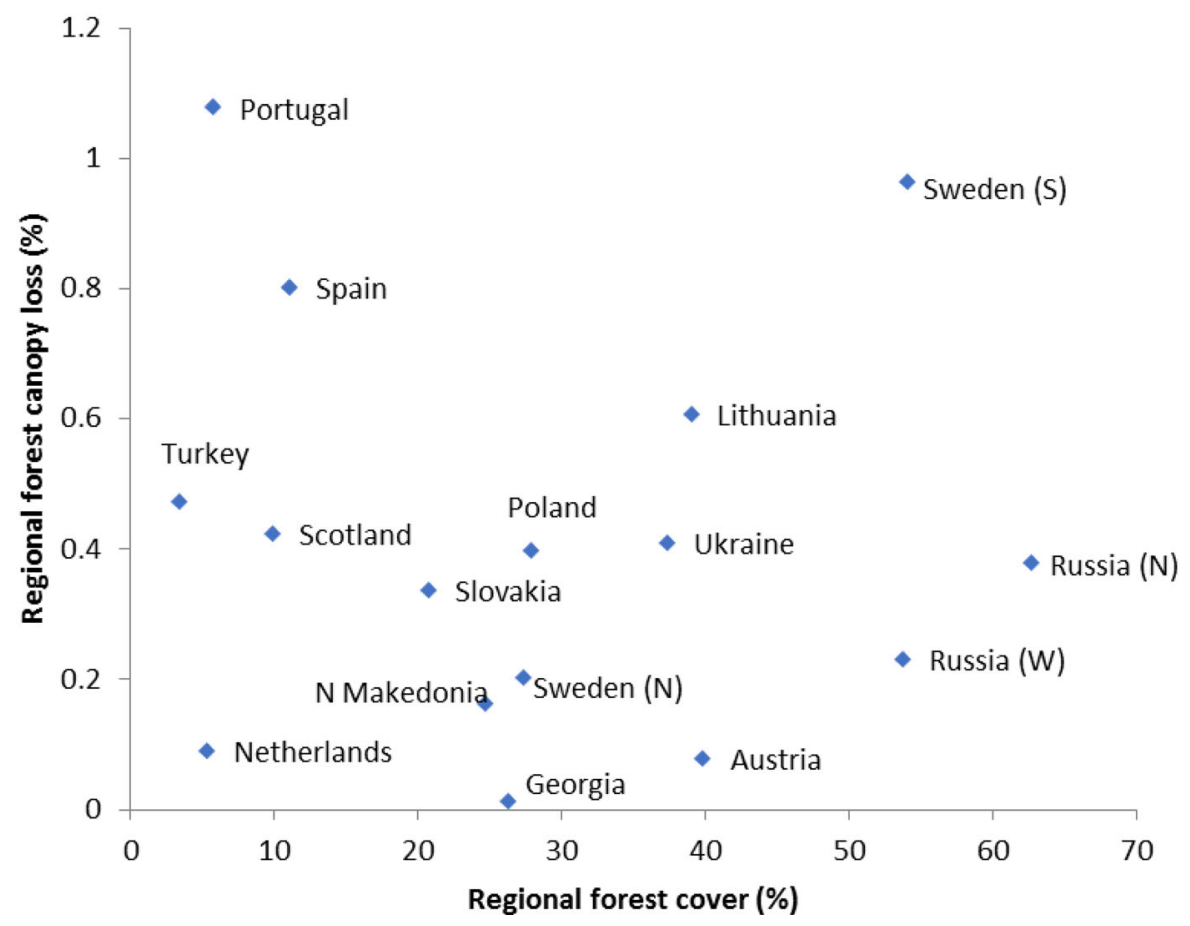

Fig. 9 Regional annual forest canopy loss Hansen et al. (2013) for the period 2000-2018 in relation to forest cover in 16 Pan-European case study regions

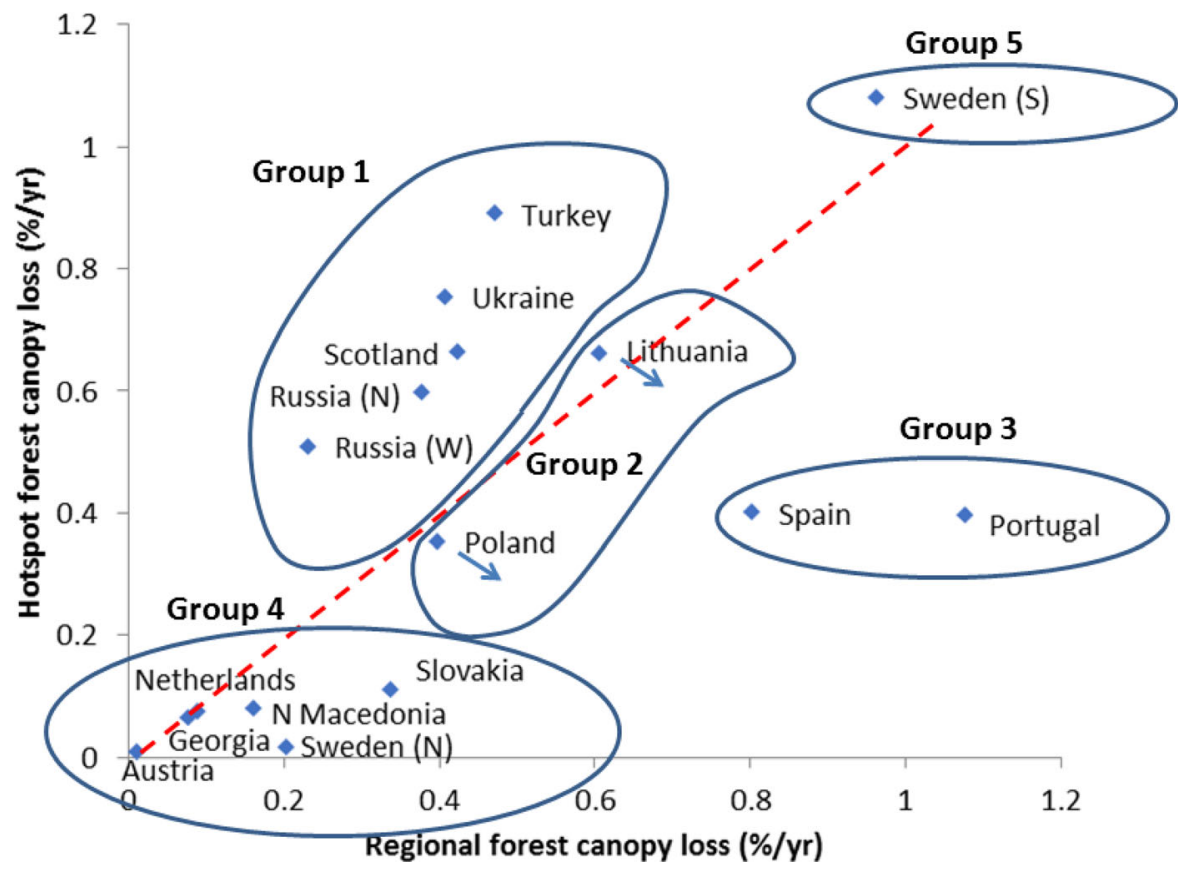

Fig. 10 Relationships between forest canopy loss 2000-2018 according to Hansen et al. (2013) among the 16 regional case studies and hotspot landscapes. The five groups are labelled (1) radical transformation of landscapes, (2) abuse of "protected area" concepts, (3) ancient cultural "savannah" hotspot remnants in a region of transformation, (4) "multi-functional forest", and (5) intensive even-aged forest management 
They illustrate that forest canopy loss rates can be higher than expected from hotspots' status as protected areas (e.g., Biosphere Reserve, National park, Natura 2000, World Heritage Site). In Poland, parts of the Bialowieza forest massif are documented as habitat for species dependent on primeval forests with high levels of naturalness (e.g., Angelstam and DönzBreuss 2004). Nevertheless, forestry for wood production is being carried out in parts of this forest massif, and recently also highly debated salvage logging following increased bark beetle abundance took place (Mikusiński et al. 2018; Blicharska et al. 2020). Also other sanitary cuttings is a way to harvest forest, such as continuous removal of deadwood in Poland and Lithuania. In Lithuania, forest privatisation as an opportunity for rapidly increasing income generation in the National Park Dzukija has resulted in rapidly increasing forest canopy losses (see Online Appendix). This is linked to extensive afforestations made a century ago, the resulting forests of which are now mature for final felling are being harvested.

A third group with much lower hotspot canopy losses than expected from the regional average were observed in semi-natural"savannahs" in terms of Dehesas in Spain (Joffre et al. 1999) and Montados in Portugal (Pinto-Correia et al. 2011). Among Mediterranean and temperate forest regions with expanding forest cover (i.e. in "forest transition" sensu Mather 1992), Portugal differs because this trend has recently been reverted (Oliveira et al. 2017). However, there is large regional variation, both related to climate and human occupation and land tenure, especially between the northern and southern halves of the country. In the south, where our case study region is located, shrublands were transformed to oak woodlands and agricultural lands during the first half of the twentieth century, after which both oak woodlands and forest plantations have increased, as did high severity wildfire more recently (Oliveira et al. 2017). Introduced Eucalypt spp. and Pinus pinaster plantations, both expanding largely after the 1950s, are particularly fire-prone (e.g., Fernandes and Rigolot 2007). Land tenure, rooted in the Middle Ages and the "reconquista" wars has had a tremendous impact in the Spanish and Portuguese landscapes. There is a gradient from northern to southern Spain and Portugal where small ownership units dominate in the north and big properties with industrialized agriculture in Antiquity (Roman latifundios, i.e. spacious estate) in the south, the Portuguese Alentejo case study region being a paradigmatic example. Another special ownership distinction is that the forest properties derived from the liberal auctions (desamortizaciones). During this process, which lasted from the late eighteenth century to late 19th and even early twentieth century, properties belonging to the Church and its religious orders, municipalities and even universities were confiscated and sold in public auctions to private tenants. As reaction, this resulted in the creation of both public forest portfolios, and of collective forests. The first was based on public lands that were excluded from confiscation due to its importance for erosion control following forest clearing for agricultural purposes, and use of particular land covers or tree species. The second was the collective effort to restore ownership by buying back the land. In Spain, 29\% of forest cover is public while $70 \%$ is private (including collective properties) and the remaining $1 \%$ has unknown owner (Alberdi et al. 2016). As a consequence, parts of the case study region Palencia have considerable areas with plantations on public land of Pinus nigra, $P$. pinaster and $P$. sylvestris. Mortality due to pine processionary moth (Thaumetopoea pityocampa) and pine wood nematode (Bursaphelenchus xylophilus) occurs, and is expected to increase with reduced winter temperatures (Pérez et al. 2017). In contrast, in the hotspot area native oak woodlands are widespread and subject to selective fuelwood harvesting and grazing by sheep and cows. In the Portuguese case the expansion of these silvo-pastoral systems is related to public support campaigns, the subsequent rural exodus and land abandonment that followed, and more recently the expansion of irrigated agriculture in the region, which is now resulting in a qualitative and quantitative decline of these traditional cultural landscapes (Godinho et al. 2014).

The fourth group was formed by hotspot landscapes with very low forest canopy losses characterised by different kinds of "multi-functional forest" management. This was made up of three contexts. First, the Austrian, Georgian and North Macedonian regional landscapes are all mountainous. In the Austrian case study region continuous cover forest management methods dominate, with the aim to secure protective functions linked to steep slopes and avalanches as well as multiple uses (see Online Appendix). The Georgian and North Macedonian hotspot landscapes are protected areas (IUCN categories I, II) and landscapes 
(IUCN category V) allowing forest use only for local inhabitants' need. These form interesting practical examples of sustaining traditional cultural landscapes, including ecological, social and cultural legacies through area-based landscape approach solutions including application of different protected area categories and decentralized governance and involvement of local people (Kavtarishvili 2015; Svajda et al. 2020), as well as the range of challenges such regions are faced with (Milanovic and Djordjevic-Milosevics 2016). Second, forests in case study regions and hotspots in the Netherlands and Slovakia are managed mainly for recreational purposes, and are also associated to low forest canopy loss. In Slovakia this is due to the Protected Landscape Area "Little Carpathians" being a protected bird area with recreational forests in the city of Bratislava. Forestry here focuses exclusively on the protection of biodiversity, diversity and stability of forests. Finally, the north Swedish hotspot is dominated by low productive forest in protected areas, most of which are part of one of Sweden's remaining intact forest landscapes with very limited wood harvesting (Jonsson et al. 2019).

The fifth group, the south Swedish Örebro case study region and hotspot landscape, has a $>200$-year history of intensive forest management aimed at high sustained production of industrial raw materials and biomass (e.g., Angelstam et al. 2013). This area is characterized by high forest canopy loss associated with intensive even-aged forest management based on clear-felling and about 10 subsequent silvicultural treatments during one forest rotation of ca. 70 years (Elbakidze et al. 2013).

\section{Discussion}

Both natural forest and cultural landscapes form important GIs

With a historic perspective forest cover loss leading to deforestation has been a continuous process that has been progressing for Millennia (Kaplan et al. 2009; Zanon et al. 2018), although at different rates throughout temporal scales and socio-historical contexts. The same applies to the anthropogenic transformation of semi-natural land cover types towards cultural landscapes (e.g., Agnoletti 2014; Manton and Angelstam 2018). This study thus highlights that there are many types of land covers that need to be considered in GI planning and maintenance, and that these relate to several different contexts for GI maintenance on the European continent. Pan-European regions thus range from the last large intact forest landscapes (Potapov et al. 2017) in northern Fennoscandia (Jonsson et al. 2019) and NW Russia (Angelstam et al. 2020b) to severely fragmented forests in Western Europe and the Mediterranean. They also range from traditional multi-functional rural cultural landscapes in the European continent's economic peripheries (Butlin and Dodgshon 1998) to intensively managed ones with a mono-culture approach (EEA 2006).

Our case study approach confirms the range of forest management intensity clusters identified by Duncker et al. (2012), see Table 2, but also stresses that (1) there are examples of ongoing radical transformation of hotspot landscapes: (a) from unmanaged and close-to-nature to intensive even-aged (Russia N vs. Russia W and Ukraine, respectively; (b) from intensive even-aged forestry to combined objective and re-wilding (Scotland), and from combined objectives to even-aged forestry (Turkey); (c) from unmanaged and close-to-nature to even-aged forestry (Lithuania and Poland). Moreover, there are clear examples of (2) spatial segregation of combined objective forest and woodland management, and short-rotation forestry (Portugal and Spain), as well as (3) integration through close-to-nature and combined objective forestry (Austria, Georgia, N Macedonia, Netherlands, Slovakia, Sweden N). Finally, there is (4) intensive even-aged forest management (Sweden S). Potential natural forest vegetation types, including a wide range of developing stages after locally and regionally typical natural disturbances (Seidl et al. 2020), represent important visions for functionally connected and representative GIs (see CBD 2010). Primary or primeval forests are naturally regenerated forests of native species where there are no clearly visible indications of human impacts and where ecological processes are not significantly disturbed (FAO 2015). A high level of naturalness is a rare landscape feature, and concepts like High Conservation Value Forests (HCVF) (Jennings et al. 2003) and High Nature Value (HNV) traditional farming systems in terms of traditional cultural landscapes such as wooded grasslands (Bignal and Mccraken 2000; Ferraz-de-Oliveira et al. 2016) were therefore 
Table 2 Cross-tabulation of the five clusters GI contexts observed in this study (columns), and Duncker's et al. (2012) typology for five different forest management intensities (rows), and (see Fig. 10)

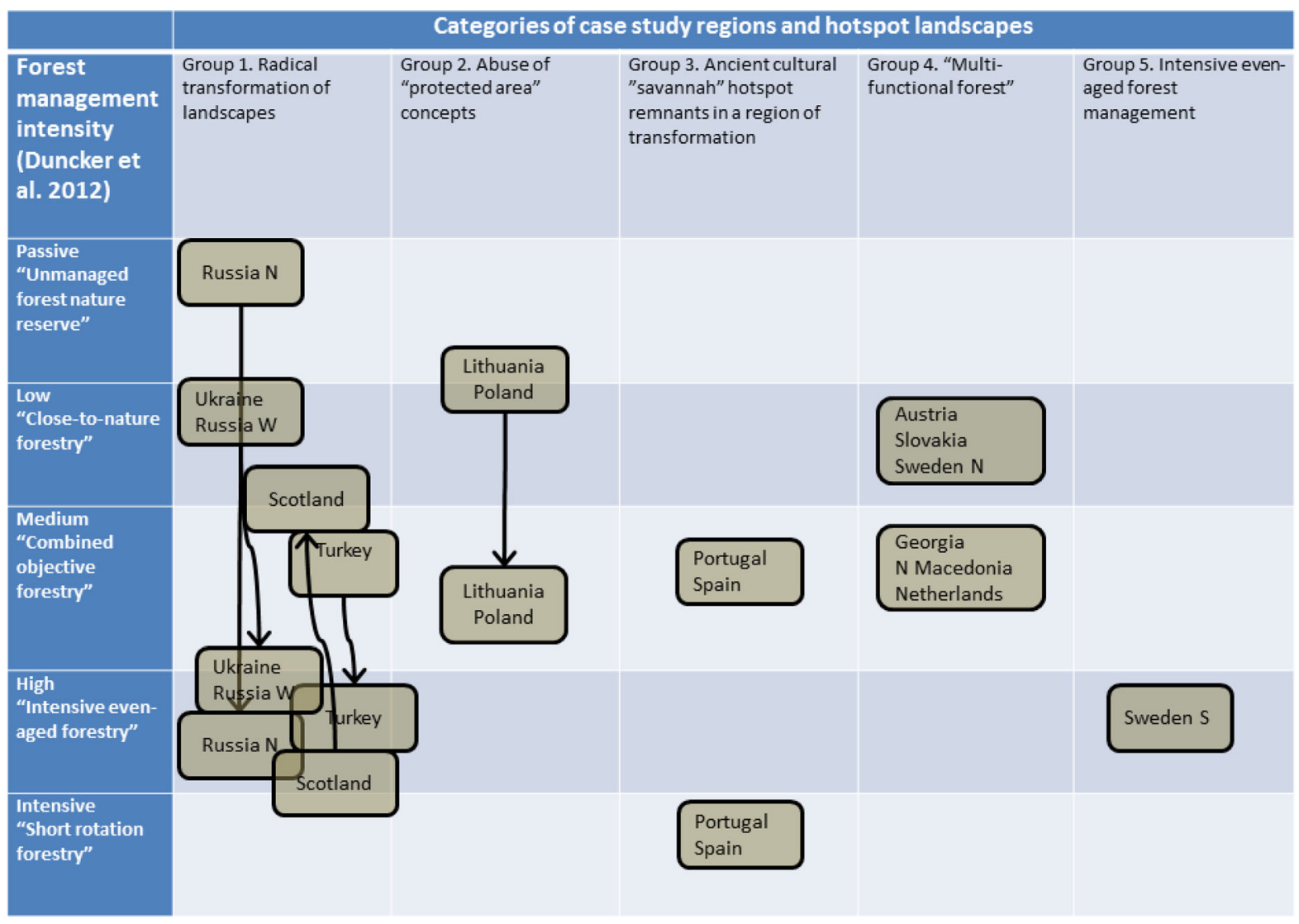

developed to highlight the role of higher levels of naturalness for in situ conservation of biodiversity. Additionally, such areas can serve as benchmarks for landscape restoration where this is needed (e.g., Kuuluvainen 2002). However, there are many definitions of naturalness (e.g., Buchwald 2005). The European Environmental Agency uses a three-level scale, viz. undisturbed by man [sic], semi-natural forest, and plantation. The first highest level of forest naturalness (undisturbed by man) is where (1) natural forest dynamics exist as reflected by tree composition, occurrence of dead wood, natural age structure at stand and landscape levels, and natural regeneration processes; (2) the area is large enough to maintain its characteristics; (3) the last significant human intervention has taken place long enough ago to allow reestablishment of the natural composition of species and processes (EEA 2006). Depending on the biodiversity property, the delivery time for restoration ranges from days (e.g., creation of habitat through fire disturbance for pyrophilous insects and plants) to decades (e.g., encouraging particular trees species and successional stages) and centuries (veteran trees, standing and lying dead wood in different stages of decay). Natural processes can inspire forest management for biodiversity conservation. Thus, we also argue for the use low intensity prescribed fire and rewetting of drained areas to restore GIs.

Traditional cultural landscapes hold endangered qualities, in terms of both biocultural legacies and cultural heritage, and constitute important habitat networks as components of a GI. Remaining regionally common biocultural legacies include oak pastures (e.g., in Portugal (Montados), Romania, Spain 
(Dehesas), Sweden), tree avenues (e.g., in Poland and Sweden) and entire landscapes with pollarded trees (e.g. in Turkey). Many native species that use these cultural landscape habitats, such as the bark and hollows of veteran trees, for nesting and feeding are also found in primary forests with high levels of naturalness. In fact, traditional rural landscapes' wood pastures host the same number of woodpecker species as near-natural forests (Dorresteijn et al. 2013). However, frequently the management regimes that created these cultural landscapes are no longer economically feasible. Their survival calls both for area protection, and effective management (e.g., Babai et al. 2015) that emulates the management of traditional cultural landscapes based on combination of horticulture, agriculture and animal husbandry. However, the traditional cultural landscape vision is partly satisfied today only in remote rural areas where low-intensity agricultural management is maintained (Halada et al. 2011). Frequently these landscapes are threatened by rural depopulation, agricultural intensification (Ferraz-de-Oliveira et al. 2016) and urbanization, but can sometimes be improved through landscape restoration, and development of value chains based on multi-functional landscapes and non-wood forest products (Segur 2014). Thus, current land-use trajectories imply continued abandonment of semi-natural grasslands, and increased forest area, thus deleting the evidence of past human influence. This offers opportunities towards re-wilding as a conservation strategy supporting rural development (Pereira and Navarro 2015), which may also contribute to expelling people from the countryside in the same was as intensive forestry does (Jørgensen 2015). Burrascano et al. (2016) reviewed the main EU policies targeting forests and grasslands and identified important conflicts between policies aimed at increased carbon sequestration versus farmland biodiversity conservation, including cultural heritage and biocultural values. They suggested three measures for tackling these conflicts: (1) integration across different policy sectors; (2) focus on multiple ecosystem services and biodiversity rather than on carbon management only; (3) highlight the importance of low-intensity farmland systems for their multifunctionality.
Pan-European contexts as natural experiments for learning

GIs as functional habitat networks at country and regional levels are shaped by the diversity of landscapes' ecology, history, climate, socio-political and cultural states and trends. Using the variation in historic permanent deforestation and recent forest canopy transitions, the 16 case study areas illustrate that multiple comparative studies can be used to identify a wide range of contexts for maintenance of different kinds of GI. This is a novel approach, which acknowledges that differences and boundaries between countries and regions often represent gradients and demarcation lines specific to patterns of heterogeneity in many dimensions, thus serving as cornerstones for understanding landscapes as socialecological systems. Reducing their variety to two essential types that rarely coincide, ecological boundaries (EB) and socio-political boundaries (SPB) emerge as the most common. EB are structural and functional components of the "habitat mosaic", which refer to particularities emphasized by the more specific terms that designate them at different scales: edges, gradients, clines, ecoclines, ecotones, interfaces, transition zones or boundary layers (Cadenasso et al. 2003; Yarrow and Marín 2007; Dallimer and Strange 2015). On the other hand, SPB are social constructs created to clarify ownership rights and regulations enforcement (Van Houtum and Van Naerssen 2002).

By hindering effective coordination on opposite sides of the separation line, boundaries tend to have repercussions on GI management and may be regarded as complicating factors for biodiversity conservation, as they are associated with the fragmentation of governance and of ownership. Similar to the arbitrary setting of the African boundaries that lead to various socio-economic detrimental consequences highlighted by McCauley and Posner (2015), the mismatched realities of the EBs and SPBs offers opportunity for viewing these cases as natural experiments (Diamond 1983). Such experiments are particularly useful to further the knowledge regarding the ecosystem services that are performed across the international political borders and the influence the drivers in one state exert over the ecosystems and livelihood of the communities in the bordering state(s) (López-Hoffman et al. 2010). 
Thus, the main concern is that SPB fulfil no ecological function, but crisscross ecosystems that become subject to the influence of different governance institutions, programmes and strategies (Dallimer and Strange 2015). The differences regarding the management system, the attitudes and values that the human communities develop on the sides of the borders impact the conservation practices and instruments that should have a common ground as they deal with one and the same ecosystem that extends beyond certain SPBs (Angelstam et al. 2020b).

The issues that contribute to the reduction of ecological coherence call for coordinated transboundary conservation efforts, which have been proven to increase efficiency (Chernovsky 1996; Fall 2003; Kark et al. 2009; Opermanis et al. 2012), and also help avoiding conflicts between the distinct management systems across the boundary (Dallimer and Strange 2015). Transboundary collaborations targeting biodiversity preservation take the form of conventions or treaties applied at global, regional and multilateral levels. Leibenath et al. (2010) provided a literature review of the transboundary cooperation projects in Central Europe, but the performance assessment of the cross-border protected areas is an emerging scientific research field (Parrish et al. 2003; Ardron 2008; Opermanis et al. 2012).

The transboundary Polish-Belarusian Bialowieza forest massif (BFM) is an interesting example. The bilateral BFM is a mosaic of natural heritage and cultural heritage much less affected by forest clearing and management that reduce the level of naturalness. This pattern is consistent with the historic development of early frontiers throughout Europe of localized more or less temporary livelihoods. Here zoning efforts that would reduce antagonism between forestry and conservation call for a larger spatial extent of spatial planning than just BFM in Poland, or just in Belarus (Jaroszewicz et al. 2019; Blicharska et al. 2020). This approach is relevant along European border areas in terms of establishing a "green belt" (Marschall et al. 2012; Jonsson et al. 2019). Further interesting mismatches in governance may be encountered between the Portuguese Montado and the Spanish Dehesa, which are exactly similar systems, but with different models of governance and policy across the Spanish-Portuguese border, resulting in different social-ecological impacts.
We thus advocate the use of regions and landscapes as benchmarks and references from which knowledge can be derived and applied elsewhere. In this study the Scottish and Turkish case study areas are particularly instructive regarding frontiers of landscape change. In Scotland, beginning a century, ago conifer plantations grew fast on woodland areas to secure wood as a provisioning ecosystem services. However, societal demands eventually changed in favour of oak woodlands as habitat for wild species and attractive landscape (Burton et al. 2019). In the Turkish case study cultural oak woodlands have been maintained for centuries to supply feed for domestic herbivores in a transhumance system, but are now faced with a wave of conifer plantations. This, as well as other contrasting examples, offers interesting opportunities for knowledge production and learning about scale mismatches in social-ecological systems (Cumming et al. 2006).

Adapting spatial planning of landscapes to context

Accommodating the simultaneous delivery of multiple goods, services and values from landscapes requires a diversity of approaches centred at the landscape level. There is no single right way to manage forests and cultural landscapes, and spatially design landscapes as a necessary foundation for sustainable rural and regional development (e.g., Niedziałkowski et al. 2019). A mixture, at the landscape level, of forests with high levels of naturalness, semi-natural forests and forest plantations, as well as traditional farming systems, depending on the social-ecological context, are needed to fulfill different societal aims both form the urban to the rural communities. Maintaining GI through area protection, habitat management and restoration, combined with integrated landscape planning, also stresses the need to adapt approaches and strategies to the regional and landscape context (Lazdinis et al. 2019), to land ownership patterns (Angelstam et al. 2020a), and address spatial and temporal scale mismatch problems (Cumming et al. 2006).

Land sharing and land sparing are two opposite and much discussed approaches that illustrate the tension between integrative vs. segregative approaches to land use (Edwards et al. 2014; Paul and Knoke 2015). Land-sharing is indeed illustrated well by traditional cultural woodlands (e.g., Pinto-Correia et al. 2011; 
Ekroos et al. 2013; Ferraz-de-Oliveira et al. 2016; Garrido et al. 2017). However, for forest ecosystems where naturalness is the conservation vision we advocate a focus on landscape level where sufficient proportion of land-sparing cohabits with intensive and multifunctional areas under the land sharing framework (Oehri et al. 2020). This is also well in line with predictions from theoretical analysis that strongly suggest that a concentration of areas with high quality habitats of a particular forest biotope is superior for maintaining viable populations (Hanski 2011; Rybicki and Hanski 2013).

Thus, Iojă et al. (2010) and Angelstam et al. (2020a) concluded that a regional landscape planning approach to conserving biodiversity and human wellbeing based on spatial prioritization, rigorous scientific documentation, and social acceptance among land owner categories is urgently needed to secure functional representative habitat networks as GI. The triad model is a good example, in which three basic approaches to management are recognized: (1) reserves in which areas are set-aside and their values maintained; (2) production areas where sustained yield is emphasized; and 3) an overall matrix where multiple benefits are satisfied (Seymour and Hunter 1992, 1999).

Finally, in the current period of rapid global change including climate shifts, biodiversity decline, urbanisation, agricultural intensification and pandemics (Vitousek 1994; Crutzen 2006) questions surrounding the naturalness vision and potential natural vegetation types and their dynamic, and the maintenance of traditional cultural landscapes are inherently affected. Landscape stewardship in a changing world does not discount the significant need for appreciation of, and learning from, the historic trajectories of the cases we have collated. However, it is impossible to ignore the fact that the 'goalposts' may have changed over the last decades with respect to these compounding factors. 'What 'should' landscape stewardship look like in a changing world?' then becomes a much more complex question, which requires understanding of not only of ecosystems, but also human cultural legacies (Inglehart 2018), and how traditional, new and virtual fora for social interactions can contribute to learning (Angelstam et al. in press).

\section{Conclusions}

Our comparison of 16 case study regions and constituent hotspot landscapes illustrate the diversity of social-ecological contexts and transition trajectories that the maintenance of representative green infrastructures needs to handle. Once dominated by naturally dynamic forests, Pan-European regions of particular importance for sustaining green infrastructures range from those built on remaining areas with a high level of naturalness, to those built on traditional low-intensity farming including animal husbandry. While the former requires protected area networks allowing natural disturbance regimes, the latter requires maintenance of traditional multifunctional agricultural systems. This means that both historic permanent loss of forests as potential natural vegetation, and current transition trajectories need to be understood. It is important to differ between deforestation and temporary canopy loss caused by forestry and natural disturbances, and both can lead to counterintuitive losses as well as gains of biodiversity. Comparative studies of regions and landscapes across the European continent as a "time machine" can support knowledge production and learning about how to sustain GI in different contexts.

Acknowledgements This work was supported by the AlterNet High Impact Action 2018-20, and the FORMAS Grant 2017:1342 to Per Angelstam. Robert Kanka and Zita Izakovičová received funding from the VEGA Grant $\mathrm{Nr}$. 2/0078/18, and José Muñoz-Rojas from the LIAISON Project (H2020- Grant Agreement No 773418).

Funding Open access funding provided by Swedish University of Agricultural Sciences.

Open Access This article is licensed under a Creative Commons Attribution 4.0 International License, which permits use, sharing, adaptation, distribution and reproduction in any medium or format, as long as you give appropriate credit to the original author(s) and the source, provide a link to the Creative Commons licence, and indicate if changes were made. The images or other third party material in this article are included in the article's Creative Commons licence, unless indicated otherwise in a credit line to the material. If material is not included in the article's Creative Commons licence and your intended use is not permitted by statutory regulation or exceeds the permitted use, you will need to obtain permission directly from the copyright holder. To view a copy of this licence, visit http://creativecommons.org/licenses/by/4.0/. 


\section{References}

Agnoletti M (2014) Rural landscape, nature conservation and culture: some notes on research trends and management approaches from a (southern) European perspective. Landsc Urban Plan 126:66-73

Agnoletti M, Emanueli F (2016) Biocultural diversity and landscape in Europe: framing the issue. In: Agnoletti M, Emanueli F (eds) Biocultural diversity in Europe. Environmental history, vol 5, 1st edn. Springer, Cham, pp 1-18

Alberdi I, Hernández L, Condés S, Vallejo R, Cañellas I (2016) Spain. In: Vidal C, Alberdi I, Hernández L, Redmond JJ (eds) National Forest inventories assessment of wood availability. Springer, Cham, pp 749-768

Angelstam P, Andersson L (2001) Estimates of the needs for forest reserves in Sweden. Scand J For Res Suppl 3:38-51

Angelstam P, Dönz-Breuss M (2004) Measuring forest biodiversity at the stand scale-an evaluation of indicators in European forest history gradients. Ecol Bull 51:305-332

Angelstam P, Boresjö-Bronge L, Mikusiński G, Sporrong U, Wästfelt A (2003a) Assessing village authenticity with satellite images: a method to identify intact cultural landscapes in Europe. AMBIO: J Hum Environ 32(8):594-604

Angelstam PK, Bütler R, Lazdinis M, Mikusiński G, Roberge JM (2003b) Habitat thresholds for focal species at multiple scales and forest biodiversity conservation-dead wood as an example. Ann Zool Fenn 40:473-482

Angelstam P, Axelsson R, Elbakidze M, Laestadius L, Lazdinis M, Nordberg M, Pătru-Stupariu I, Smith M (2011) Knowledge production and learning for sustainable forest management on the ground: Pan-European landscapes as a time machine. Forestry 84:581-596

Angelstam P, Andersson K, Isacson M, Gavrilov D, Axelsson R, Bäckström M, Degerman K, Elbakidze M, Kazakova-Apkarimova E, Sartz L, Sädbom S, Törnblom J (2013) Learning about the history of landscape use for the future: consequences for ecological and social systems in Swedish Bergslagen. Ambio 42(2):150-163

Angelstam P, Manton M, Pedersen S, Elbakidze M (2017a) Disrupted trophic interactions affect recruitment of boreal deciduous and coniferous trees in northern Europe. Ecol Appl 27(4):1108-1123

Angelstam P, Pedersen S, Manton M, Garrido P, Naumov V, Elbakidze M (2017b) Green infrastructure maintenance is more than land cover: large herbivores limit recruitment of key-stone tree species in Sweden. Landsc Urban Plan 167:368-377

Angelstam P, Yamelynets T, Elbakidze M, Prots B, Manton M (2017c) Gap analysis as a basis for strategic spatial planning of green infrastructure: a case study in the Ukrainian Carpathians. Écoscience 24(1-2):41-58

Angelstam P, Naumov V, Elbakidze M, Manton M, Priednieks J, Rendenieks Z (2018) Wood production and biodiversity conservation are rival forestry objectives in Europe's Baltic Sea Region. Ecosphere 9(3):e02119

Angelstam P, Munoz-Rojas J, Pinto-Correia T (2019) Landscape interpretations and landscape approach initiatives can foster knowledge production and learning that sustain multiple ecosystem services. Landsc Ecol 34(7):1445-1460
Angelstam P, Manton M, Green M, Jonsson BG, Mikusinski G, Svensson J, Sabatini FM (2020a) High conservation value forest remnants in Sweden do not satisfy agreed biodiversity targets: a call for adaptive landscape planning. Landsc Urban Plan 202:103838

Angelstam P, Manton M, Yamelynets T, Sørense OJ, Kondrateva SV (2020b) Landscape approach towards integrated conservation and use of primeval forests: the transboundary Kovda river catchment in Russia and Finland. Land 9:144

Angelstam P, Fedoriak M, Cruz F, Muñoz-Rojas J, Yamelynets T, Manton M, Washbourne C, Dobrynin D, Izakovicova Z, Jansson N, Jaroszewicz B, Kanka R, Kavtarishvili M, Kopperoinen L, Lazdinis M, Metzger M, Özut D, Gjorgieska DP, Sijtsma F, Stryamets N, Tolunay A, Turkoglu T, van der Moolen B, Zagidullina A, Zhuk A. Meeting places and social capital supporting rural landscape stewardship: A Pan-European horizon scanning. Ecology and Society (In Press)

Ardron JA (2008) The challenge of assessing whether the OSPAR network of marine protected areas is ecologically coherent. Challenges to marine ecosystems. Springer, Dordrecht, pp 45-53

Arnborg T (1990) Forest types of northern Sweden. Vegetatio 90:1-13

Atalay I, Efe R, Östürk M (2014) Ecology and classification of forests in Turkey. Procedia: Soc Behav Sci 120:788-505

Axelsson AL, Östlund L (2001) Retrospective gap analysis in a Swedish boreal forest landscape using historical data. For Ecol Manage 147(2-3):109-122

Babai D, Tóth A, Szentirmai I, Biró M, Máté A, Demeter L, Szépligeti M, Varga A, Molnár Á, Kun R, Molnár Z (2015) Do conservation and agri-environmental regulations effectively support traditional small-scale farming in EastCentral European cultural landscapes? Biodivers Conserv 24(13):3305-3327

Bascompte J, Solé RV (1996) Habitat fragmentation and extinction thresholds in spatially explicit models. J Anim Ecol 65:465-473

Bergner A, Sunnergren A, Yeşilbudak B, Erdem C, Jansson N (2016) Attributes of trees used by nesting and foraging woodpeckers (Aves: Picidae) in an area with old pollarded Oaks (Quercus spp.) in the Taurus Mountains, Turkey. Zool Middle East 62(4):288-298

Bignal EM, Mccraken DI (2000) The nature conservation value of European traditional farming systems. Environ Rev 8:149-171

Blanco E, Casado MA, Costa M, Escribano R, García M, Génova M, Gómez A, Gómez F, Moreno JC, Morla C, Regato P, Sainz H (1997) Los bosques ibéricos. Una interpretación geobotánica, Planeta, Barcelona

Blicharska M, Angelstam P, Jacobsen JB, Giessen L, Hilszczanski J, Hermanowicz E, Holeksa J, Jaroszewicz B, Konczal A, Konieczny A, Mikusinski G, Mirek Z, Muys B, Mohren F, Niedzialkowski K, Samojlik T, Sotirov M, Sterenczak K, Szwagrzyk J, Winder GM, Witkowski Z, Zaplata R, Winkel G (2020) Contested evidence and the multifaceted nature of biodiversity conservation and sustainable land use-the emblematic case of Białowieża Forest. Biol Conserv 248:108614 
Blumröder JS, Hoffmann MT, Ilina O, Winter S, Hobson PR, Ibisch PL (2020) Clearcuts and related secondary dieback undermine the ecological effectiveness of FSC certification in a boreal forest. Ecol Process 9(1):1-9

Bobiec A, Podlaski R, Ortyl B, Korol M, Havryliuk S, Öllerer K, Ziobro JM, Pilch K, Dychkevych V, Tomasz D, Mázsa K, Varga A, Angelstam P (2019) Top-down segregated policies undermine the maintenance of traditional wooded landscapes: evidence from oaks at the European Union's eastern border. Lands Urban Plan 189:247-259

Bohn U, Gollub G, Hettwer C (2000) Map of the natural vegetation of Europe. Explanatory text with CD-ROM. Federal Agency for Nature Conservation, Bonn-Bad Gotesberg

Bohn U, Neuhäusle R, Gollub G, Hettwer C, Neuhäuslová Z, Raus T, Schlüter H, Weber H (2003) Map of the natural vegetation of Europe. Explanatory text with CD-ROM. Bonn: German Federal Agency for Nature Conservation. http://www.floraweb.de/vegetation/dnld_eurovegmap. html. Accessed 14 Sept 2020

Bravo F, Montero G (2001) Site index estimation in Scots pine (Pinus sylvestris L.) stands in the High Ebro Basin (Northern Spain) using soil attributes. Forestry 74(4):395-406

Broxton PD, Zeng X, Sulla-Menashe D, Troch PA (2014) A global land cover climatology using MODIS data. J Appl Meteor Climatol 53(6):1593-1605

Buchwald E (2005) A hierarchical terminology for more or less natural forests in relation to sustainable management and biodiversity conservation. In Proceedings: third expert meeting on harmonizing forest-related definitions, Rome, pp 111-127

Burrascano S, Chytrý M, Kuemmerle T, Giarrizzo E, Luyssaert S, Sabatini FM, Blasi C (2016) Current European policies are unlikely to jointly foster carbon sequestration and protect biodiversity. Biol Conserv 201:370-376

Burton V, Metzger MJ, Brown C, Moseley D (2019) Green gold to wild woodlands; understanding stakeholder visions for woodland expansion in Scotland. Landsc Ecol 34:1693-1713

Butlin RA, Dodgshon PA (1998) A historical geography of Europe. Oxford University Press, Oxford

CBD (Convention on Biological Diversity) (2010) The strategic plan for biodiversity 2011-2020 and the aichi biodiversity targets, Nagoya, Japan. https://www.cbd.int/sp/. Accessed 26 June 2020

CBD (Convention on Biological Diversity) (2020) Zero draft of the post-2020 global biodiversity framework, Kunming, China. https://www.cbd.int/conferences/post2020/ wg2020-02/documents. Accessed 26 June 2020

COPERNICIS (2019) Corine Land Cover 2018 https://land. copernicus.eu/pan-european/corine-land-cover/clc2018. Accessed 26 June 2020

Cadenasso ML, Pickett ST, Weathers KC, Bell SS, Benning TL, Carreiro MM, Dawson TE (2003) An interdisciplinary and synthetic approach to ecological boundaries. Bioscience 53(8):717-722

Cajander AK (1926) The theory of forest types. Acta For Fenn 29(3):1-108

Ceccherini G, Duveiller G, Grassi G, Lemoine G, Avitabile V, Pilli R, Cescatti A (2020) Abrupt increase in harvested forest area over Europe after 2015. Nature 583:72-95
Chazdon RL, Brancalion PH, Laestadius L, Bennett-Curry A, Buckingham K, Kumar C, Moll-Rocek J, Guimarães Vieira IC, Wilson SJ (2016) When is a forest a forest? Forest concepts and definitions in the era of forest and landscape restoration. Ambio 45(5):538-550

Chernovsky J (1996) Biodiversity conservation in transboundary protected areas in Europe, National Research Council. Washington, DC: The National Academies Press. https:// www.nap.edu/catalog/5370/biodiversity-conservation-intransboundary-protected-areas. Accessed 14 Sept 2020

Chmiliar L (2010) Multiple-case designs. In: Mills AJ, Durepos G, Wiebe E (eds) Encyclopedia of case study research. SAGE Publications, Thousand Oaks, pp 583-584

Creswell JW (2007) Research design: qualitative, quantitative, and mixed methods approaches. Sage Publications, Thousand Oaks

Crutzen PJ (2006) The "anthropocene.” Earth system science in the anthropocene. Springer, Berlin, pp 13-18

Cumming GS, Cumming DHM, Redman CL (2006) Scale mismatches in social-ecological systems: causes, consequences, and solutions. Ecol SOC 11(1):14

Dallimer M, Strange N (2015) Why socio-political borders and boundaries matter in conservation. Trends Ecol Evol 30(3):132-139

Diamond JM (1983) Ecology: laboratory, field and natural experiments. Nature 304(5927):586-587

Dobrovodská M, Kanka R, David S, Kollár J, Špulerová J, Štefunková D, Mojses M, Petrovič F, Krištín A, Stašiov S, Halada L (2019) Assessment of the biocultural value of traditional agricultural landscape on a plot-by-plot level: case studies from Slovakia. Biodivers Conserv 28(10):2615-2645

Dorresteijn I, Hartel T, Hanspach J, von Wehrden H, Fischer J (2013) The conservation value of traditional rural landscapes: the case of woodpeckers in Transylvania, Romania. PLOS ONE 8(6):e65236

Duncker PS, Barreiro SM, Hengeveld GM, Lind T, Mason WL, Ambrozy S, Spiecker H (2012) Classification of forest management approaches: a new conceptual framework and its applicability to European forestry. Ecol Soc 17(4):51-68

EEA (European Environmental Agency) (2006) European forest types. Categories and types for sustainable forest management reporting and policy, European Environment Agency: Copenhagen, Denmark, EEA Technical Report 09/2006, 2nd ed. https://www.foresteurope.org/docs/ other_meetings/2006/wfc/WFC_4_eea_technical_report_ 92006.pdf. Accessed 26 June 2020

EUROSTAT (2019) LUCAS-land use and land cover survey https://ec.europa.eu/eurostat/statistics-explained/index. php/LUCAS_-_Land_use_and_land_cover_survey. Accessed 26 June 2020

Edwards DP, Gilroy JJ, Woodcock P, Edwards FA, Larsen TH, Andrews DJR, Derhé MA, Docherty TDS, Hsu WW, Mitchell SL, Ota T, Williams LJ, Laurance WF, Hamer KC, Wilcove DS (2014) Land-sharing versus land-sparing logging: reconciling timber extraction with biodiversity conservation. Glob Change Biol 20(1):183-191

Ekroos J, Rundlöf M, Smith HG (2013) Trait-dependent responses of flower-visiting insects to distance to semi- 
natural grasslands and landscape heterogeneity. Landsc Ecol 28(7):1283-1292

Elbakidze M, Andersson K, Angelstam P, Armstrong GW, Axelsson R, Doyon F, Hermansson M, Jacobsson J, Pautov Y (2013) Sustained yield forestry in Sweden and Russia: how does it correspond to sustainable forest management policy? Ambio 42(2):160-173

Ellenberg H (1988) Vegetation ecology of Central Europe. Cambridge University Press, Cambridge

Esseen PA, Ehnström B, Ericson L, Sjöberg K (1997) Boreal forests. Ecol Bull 16-47

European Commission (2013) Green infrastructure (GI)-enhancing Europe's natural capital. European Commission: Environment, Brussels

European Commission (2020) EU biodiversity strategy for 2030. Communication 380. https://ec.europa.eu/ knowledge4policy/publication/communicationcom2020380-eu-biodiversity-strategy-2030-bringingnature-back-our-lives_en. Accessed 26 June 2020

FAO (2015) Global forest resources assessment 2015. Forest resources assessment working paper 180. FAO, Rome

Fahrig L (2018) Habitat fragmentation: a long and tangled tale. Glob Ecol Biogeogr 28:33-41

Fall JJ (2003) Planning protected areas across boundaries: new paradigms and old ghosts. J Sustain For 17(1-2):81-102

Fernandes PM, Rigolot E (2007) The fire ecology and management of maritime pine (Pinus pinaster Ait.). For Ecol Manage 241:1-13

Ferraz-de-Oliveira MI, Azeda C, Pinto-Correia T (2016) Management of montados and dehesas for high nature value: an interdisciplinary pathway. Agrofor Syst 90(1):1-6

Filepné Kovács K, Valánszki I, Sallay A, Jombach S (2013) Integration of landscape planning and protection in the spatial planning practices of European countries. J Landsc Ecol 11(2):279-290

FitzHugh TW, Vogel RM (2011) The impact of dams on flood flows in the United States. River Res Appl 27(10):1192-1215

Flick U (2006) An introduction to qualitative research. Sage Publications, London

Forestry Commission (2016) Preliminary estimates of the changes in canopy cover in British woodlands between 2006 and 2015-National Forest Inventory. www. forestresearch.gov.uk. Accessed 26 June 2020

Fries C, Johansson O, Pettersson B, Simonsson P (1997) Silvicultural models to maintain and restore natural stand structures in Swedish boreal forests. For Ecol Manage 94(1):89-103

Garrido P, Elbakidze M, Angelstam P, Plieninger T, Pulido F, Moreno G (2017) Stakeholder perspectives of wood pasture ecosystem services: a case study from Iberian Dehesas. Land Use Policy 60:324-333

Godinho S, Guiomar N, Machado R, Santos P, Sá-Sousa P, Fernandes JP, Sousa-Neves N, Pinto-Correia T (2014) Assessment of environment, land management, and spatial variables on recent changes in montado land cover in southern Portugal. Agrofor Syst. https://doi.org/10.1007/ s10457-014-9757-7

Greene JC (2007) Mixed methods in social inquiry. Wiley, Hoboken
Halada L, Evans D, Romão C, Petersen JE (2011) Which habitats of European importance depend on agricultural practices? Biodivers Conserv 20(11):2365-2378

Hannah L, Carr JL, Lankerani A (1995) Human disturbance and natural habitat: a biome level analysis of a global data set. Biodivers Conserv 4(2):128-155

Hansen MC, Potapov PV, Moore R, Hancher M, Turubanova SA, Tyukavina A, Thau D, Stehman SV, Goetz SJ, Loveland TR, Kommareddy A, Egorov A, Chini L, Justice CO, Townshend JRG (2013) High-resolution global maps of 21st-century forest cover change. Science 342(6160):850-853

Hansen MC, Stehman SV, Potapov PV (2010) Quantification of global gross forest cover loss. PNAS 107(19):8650-8655

Hanski I (2011) Habitat loss, the dynamics of biodiversity, and a perspective on conservation. Ambio 40(3):248-255

Hägglund B, Lundmark JE (1977) Site index estimation by means of site properties of Scots pine and Norway spruce in Sweden. Studia Forestalia Suecica 138

IPBES (2019) Global assessment report on biodiversity and ecosystem services of the intergovernmental science- policy platform on biodiversity and ecosystem services. IPBES Secretariat, Bonn

Inglehart RF (2018) Cultural evolution. People's motivations are changing, and reshaping the world. Cambridge University Press, Cambridge

Iojă CI, Pătroescu M, Rozylowicz L, Popescu VD, Vergheleţ M, Zotta MI, Felciuc M (2010) The efficacy of Romania's protected areas network in conserving biodiversity. Biol Conserv 143(11):2468-2476

Jaroszewicz B, Cholewińska O, Gutowski JM, Zimny M, Samojlik T, Latałowa M (2019) Białowieża forest-a relic of the high naturalness of European forests. Forests 10:849-877

Jennings S, Nussbaum R, Judd N, Evans T, Iacobelli T, Jarvie J, Lindhe A, Synnott T, Vallejos C, Yaroshenko A, Chunquan Z (2003) The high conservation value forest toolkit. ProForest, Oxford

Joffre R, Rambal S, Ratte JP (1999) The dehesa system of southern Spain and Portugal as a natural ecosystem mimic. Agrofor Syst 45(1-3):57-79

Jonsson BG, Ekström M, Esseen PA, Grafström A, Ståhl G, Westerlund B (2016) Dead wood availability in managed Swedish forests-policy outcomes and implications for biodiversity. For Ecol Manage 376:174-182

Jonsson BG, Svensson J, Mikusiński G, Manton M, Angelstam P (2019) European Union's last intact forest landscape is at a value chain crossroad between multiple use and intensified wood production. Forests 10(7):564-585

Jørgensen D (2015) Rethinking rewilding. Geoforum 65:482-488

Kaplan JO, Krumhardt KM, Zimmermann N (2009) The prehistoric and preindustrial deforestation of Europe. Quat Sci Rev 28(27-28):3016-3034

Kark S, Levin N, Grantham HS, Possingham HP (2009) Between-country collaboration and consideration of costs increase conservation planning efficiency in the Mediterranean Basin. Proc Natl Acad Sci 106(36):15368-15373

Karpov AA (2019) Area reduction of intact forest landscapes on the example of the Dvina-Pinega interfluve. Lesnoy Zhurnal [Forestry Journal] 3:152-158 (in Russian) 
Kavtarishvili M (2015) Tusheti and its forests-a unique case of local governance in Georgia. J Prot Mt Areas Res 7:70-77

Keeton WS, Angelstam PK, Bihun Y, Chernyavskyy M, Crow SM, Deyneka A, Elbakidze M, Farley J, Kovalyshyn V, Kruhlov I, Mahura B, Myklush S, Nunery JS, Soloviy I, Zahvoyska L (2013) Sustainable forest management alternatives for the Carpathian Mountains with a focus on Ukraine. In: Kozak J et al (eds) The carpathians: integrating nature and society towards sustainability. Springer, Berlin, pp 331-352

Knize A, Romanyuk B (2006) Two opinions of Russia's forest and forestry. WWF Russian Programme Office, Moscow

Kuemmerle T, Chaskovskyy O, Knorn J, Radeloff VC, Kruhlov I, Keeton WS, Hostert P (2009) Forest cover change and illegal logging in the Ukrainian Carpathians in the transition period from 1988 to 2007. Remote Sens Environ 113(6):1194-1207

Kuuluvainen T (2002) Natural variability of forests as a reference for restoring and managing biological diversity in boreal Fennoscandia. Silva Fenn 36(1):97-125

Lambeck RJ (1997) Focal species: a multi-species umbrella for nature conservation. Conserv Biol 11(4):849-856

Lazdinis M, Angelstam P, Pülzl H (2019) Towards sustainable forest management in the European Union through polycentric forest governance and integrated landscape approach. Landsc Ecol 34(7):1737-1749

Leibenath M, Blum A, Stutzriemer S (2010) Transboundary cooperation in establishing ecological networks: the case of Germany's external borders. Landsc Urban Plan 94(2):84-93

Leuschner C, Ellenberg YH (2018) Ecology of central European forests. Vegetation ecology of central European forests. Springer, New York

Lotz C (2015) Expanding the space for future resource management: Explorations of the timber frontier in northern Europe and the rescaling of sustainability during the nineteenth century. Environ Hist 21(2):257-279

López-Hoffman L, Varady RG, Flessa KW, Balvanera P (2010) Ecosystem services across borders: a framework for transboundary conservation policy. Front Ecol Environ 8(2):84-91

Mansourian S, Parrotta J, Balaji P, Bellwood-Howard I, Bhasme S, Bixler RP, Boedhihartono AK, Carmenta R, Jedd T, de Jong W, Lake FK, Lataweic A, Lippe M, Rai ND, Sayer J, Van Dexter K, Vira B, Visseren-Hamakers I, Wyborn C, Yang A (2020) Putting the pieces together: integration for forest landscape restoration implementation. Land Degrad Dev 31(4):419-429

Manton M, Angelstam P (2018) Defining benchmarks for restoration of green infrastructure: a case study combining the historical range of variability of habitat and species' requirements. Sustainability 10:326-343

Marschall I, Gather M, Müller M (2012) The Green Belt as a European Ecological Network-strengths and gaps: proceedings of the 1st GreenNet conference, 31st of January 2012, Erfurt. “ Berichte des Instituts Verkehr und Raum 10. https://www.db-thueringen.de/receive/dbt_mods_ 00035010. Accessed 26 June 2020

Mather AS (1992) The forest transition. Area 24:367-379

Mather AS (2004) Forest transition theory and the reforesting of Scotland. Scot Geogr J 120(1-2):83-98
Mayer H, Aksoy H (1986) Wälder der Türkei. Gustav Fischer Verlag, Stuttgart ((In German))

McCauley JF, Posner DN (2015) African borders as sources of natural experiments promise and pitfalls. Polit Sci Res Methods 3(2):409-418

Mikusiński G, Angelstam P (2004) Occurrence of mammals and birds with different ecological characteristics in relation to forest cover in Europe-do macroecological data make sense? Ecol Bull 51:265-275

Mikusiński G, Bubnicki JW, Churski M, Czeszczewik D, Walankiewicz W, Kuijper DP (2018) Is the impact of loggings in the last primeval lowland forest in Europe underestimated? The conservation issues of Białowieża Forest. Biol Conserv 227:266-274

Milanovic J, Djordjevic-Milosevics S (2016) Biodiversity and rural livelihood in the Western Balkans. Nadodja Biblioteka Srbije, Beograd

Muñoz-Rojas J, Nijnik M, González-Puente M, Cortines-García F (2015) Synergies and conflicts in the use of policy and planning instruments for implementing forest and woodland corridors and networks; a case study in NE Scotland. For Policy Econ 57C:47-64

Naumov V, Angelstam P, Elbakidze M (2016) Barriers and bridges for intensified wood production in Russia: insights from the environmental history of a regional logging frontier. For Policy Econ 66:1-10

Naumov V, Manton M, Elbakidze M, Rendenieks Z, Priedniek J, Uglyanets S, Yamelynets T, Zhivotov A, Angelstam P (2018) How to reconcile wood production and biodiversity conservation? The Pan-European boreal forest history gradient as an "experiment." J Environ Manage 218:1-13

Niedziałkowski K, Jaroszewicz B, Kowalczyk R, Kuijper DPJ, Mikusiński G, Selva N, Walankiewicz W, Wesołowski T (2019) Effective mitigation of conservation conflicts and participatory governance: reflections on Kuboń et al. Conserv Biol 33:962-965

Oehri J, Schmid B, Schaepman-Strub G, Niklaus PA (2020) Terrestrial land-cover type richness is positively linked to landscape-level functioning. Nat Commun 11(1):1-10

Oliveira TM, Guiomar N, Baptista FO, Pereira JM, Claro J (2017) Is Portugal's forest transition going up in smoke? Land Use Policy 66:214-226

Opermanis O, MacSharry B, Aunins A, Sipkova Z (2012) Connectedness and connectivity of the Natura 2000 network of protected areas across country borders in the European Union. Biol Conserv 153:227-238

Östlund L, Zackrisson O, Axelsson A (1997) The history and transformation of a Scandinavian boreal forest landscape since the 19th century. Can J For Res 27:1198-1206

Parrish JD, Braun DP, Unnasch RS (2003) Are we conserving what we say we are? Measuring ecological integrity within protected areas. Bioscience 53(9):851-860

Paul C, Knoke T (2015) Between land sharing and land sparing what role remains for forest management and conservation? Int For Rev 17(2):210-230

Pereira HM, Navarro LM (2015) Rewilding European Landscapes. Springer, Cham

Peterken GF (1996) Natural woodland. Ecology and conservation in temperate regions. University Press, Cambridge 
Pinto-Correia T, Ribeiro N, Sá-Sousa P (2011) Introducing the montado, the cork and holm oak agroforestry system of Southern Portugal. Agrofor Syst 82:99

Plieninger T, Höcht F, Speck T (2006) Traditional land-use and nature conservation in European rural landscapes. Environ Sci Policy 9(4):317-321

Pogrebnyak PS (1955) The basics of forest typology. Publishing office of the Academy of Sciences of the Ukrainian Socialist Soviet Republic, Kiev. (In Russian)

Potapov P, Hansen MC, Laestadius L, Turubanova S, Yaroshenko A, Thies C, Smith W, Zhuravleva I, Komarova A, Minnemeyer S, Esipova E (2017) The last frontiers of wilderness: tracking loss of intact forest landscapes from 2000 to 2013. Sci Adv 3:e1600821

Potapov P, Yaroshenko A, Turubanova S, Dubinin M, Laestadius L, Thies C, Aksenov D, Egorov A, Yesipova Y, Glushkov I, Karpachevskiy M, Kostikova A, Manisha A, Tsybikova E, Zhuravleva I (2008) Mapping the world's intact forest landscapes by remote sensing. Ecol Soc 13(2):51-67

Pérez G, Díez JJ, Ibeas F, Pajares JA (2017) Assessing pine wilt disease risk under a climate change scenario in Northwestern Spain. In: Pérez G et al (eds) Managing forest ecosystems: the challenge of climate change. Springer, Cham, pp 351-365

Pülzl H, Kleinschmit D, Arts B (2014) Bioeconomy-an emerging meta-discourse affecting forest discourses? Scand J For Res 29(4):386-393

Raja NB, Aydin O, Çiçek I, Türkoĝlu N (2018) A reconstruction of Turkey's potential natural vegetation using climate indicators. J For Res 30(6):2199-2211

Ranius T, Kindvall O (2006) Extinction risk of wood-living model species in forest landscapes as related to forest history and conservation strategy. Landsc Ecol 21:687-698

Roberge JM, Angelstam P, Villard MA (2008) Specialised woodpeckers and naturalness in hemiboreal forestsderiving quantitative targets for conservation planning. Biol Conserv 141:997-1012

Rompré G, Boucher Y, Bélanger L, Côté S, Robinson WD (2010) Conserving biodiversity in managed forest landscapes: the use of critical thresholds for habitat. For Chron 86(5):589-596

Rybicki J, Hanski I (2013) Species-area relationships and extinctions caused by habitat loss and fragmentation. Ecol Lett 16(s1):27-38

Sauer CO (1925) The morphology of landscape. University of California publications in geography, vol 2. University of California Press, Berkeley

Scott JM, Davis F, Csuti B, Noss R, Butterfield B, Groves C, Anderson H, Caicco S, D'Erchia F, Edwards TC Jr, Ulliman J, Wright RG (1993) Gap analysis: a geographic approach to protection of biological diversity. Wildl Monogr. https://doi.org/10.1016/0006-3207(94)90022-1

Segur M (2014) Old solutions for today's problems in the Urbión Model Forest. In: Katila P, Galloway G, de Jong W, Pacheco P, Mery G (eds) Forests under pressure: local responses to global issues, vol. 32, IUFRO World Series, p 561. Available at: https://www.cifor.org/knowledge/ publication/5029

Seidl R, Honkaniemi J, Aakala T, Aleinikov A, Angelstam P, Bouchard M, Boulanger Y, Burton P, De Grandpré L,
Gauthiern S, Hansen W, Jepsen J, Jõgiste K, Kneeshaw D, Kuuluvainen T, Lisitsyna O, Kobayashi M, Mori A, Pureswaran D, Shorohova E, Shubnitsina E, Taylor A, Vladimirova N, Vodde F, Senf C (2020) Globally consistent climate sensitivity of natural disturbances across boreal and temperate forest ecosystems. Ecography 43:1-12

Seymour R, Hunter ML Jr (1992) Principles and applications of new forestry in spruce-fir forests of eastern North America. Maine Agricultural Experiment Station Miscellaneous Publication, University of Maine, Orono

Seymour R, Hunter ML Jr (1999) Principles of ecological forestry. In: Hunter ML (ed) Maintaining biodiversity in forest ecosystems. Cambridge University Press, Cambridge, pp 22-61

Singh SJ, Haberl H, Chertow M, Mirtl M, Schmid M (2013) Long term socio-ecological research: studies in societynature interactions across spatial and temporal scales. Springer, Berlin, pp 1-26

Spracklen BD, Spracklen DV (2020) Old-Growth forest disturbance in the Ukrainian carpathians. Forests 11(2):151

Stake R (1995) The art of case study research. Sage, Thousand Oaks

Stake RE (2013) Multiple case study analysis. Guilford Press, New York

Stake R (2003) Case studies. In: Denzin NK, Lincoln YS (eds) Strategies in qualitative inquiry. Sage, Thousand Oaks, pp 134-164

Sukachev V, Dylis N (1964) Fundamentals of forest biogeocoenology. Nauka, Moscow (In Russian)

Svajda J, Malac L, Khartisvili L (2020) Balancing development and conservation needs of stakeholders in the Tusheti Protected Landscape. J Mt Sci 17(3):709-723

Svensson J, Andersson J, Sandström P, Mikusiński G, Jonsson BG (2019) Landscape trajectory of natural boreal forest loss as an impediment to green infrastructure. Conserv Biol 33(1):152-163

Vallejo R (2005) Restoring mediterranean forest. In: Mansourian S, Vallauri D, Dudley N (eds) Forest restoration in landscapes. Beyond planting trees. Springer, New York, pp 313-319

Van Eupen M, Merzger M, Pérez-Soba M, Verburg P, Van Doorn A, Buce R (2012) A rural typology for strategic European policies. Land Use Policy 29(3):473-482

Van Houtum H, Van Naerssen T (2002) Bordering, ordering and othering. Tijdschrift voor economische en sociale geografie 93(2):125-136

Verkerk PJ, Mavsar R, Giergiczny M, Lindner M, Edwards D, Schelhaas MJ (2014) Assessing impacts of intensified biomass production and biodiversity protection on ecosystem services provided by European forests. Ecosyst Serv 9:155-165

Vitousek PM (1994) Beyond global warming: ecology and global change. Ecology 75(7):1861-1876

von Thünen JH (1826) Det Isolierte Staat in Beziehung auf Landwirtschaft und nationalökonomie. Perthes, Hamburg

Winter S (2012) Forest naturalness assessment as a component of biodiversity monitoring and conservation management. Forestry 85(2):293-304

With KA, Crist TO (1995) Critical thresholds in species responses to landscape structure. Ecology 76:2446-2459 
Worster D (2005) Doing environmental history. In: Merchant C (ed) Major problems in American environmental history. Houghton Mifflin, Boston, pp 2-9

Yaroshenko AY, Potapov PV, Turubanova SA (2001) The last intact forest landscapes of Northern European Russia. Greenpeace Russia and Global Forest Watch, Moscow, Russia. http://www.globalforestwatch.org/english/russia/ pdf/GFW_Russia_Report_en.pdf

Yarrow MM, Marín VH (2007) Toward conceptual cohesiveness: a historical analysis of the theory and utility of ecological boundaries and transition zones. Ecosystems 10(3):462-476
Yin RK (2002) Case study research: design and methods. Sage, Thousand Oaks

Zanon M, Davis BA, Marquer L, Brewer S, Kaplan JO (2018) European forest cover during the past 12,000 years: a palynological reconstruction based on modern analogs and remote sensing. Front Plant Sci 9:253

Publisher's Note Springer Nature remains neutral with regard to jurisdictional claims in published maps and institutional affiliations. 